\title{
ESPÉCIES NOVAS DE MELISSOPTILA HOLMBERG DA AMÉRICA DO SUL E NOTAS TAXONÔMICAS (HYMENOPTERA, ANTHOPHORIDAE) ${ }^{1}$
}

\section{Danúncia Urban ${ }^{2}$}

\begin{abstract}
New SPECIES of MELISSOPTILA Holmberg From SOUtH AMERICA AND TAXONOMIC NOTES (HYMENOPTERA, ANTHOPHORIDAE). Thirty one South American species of Melissoptila Holmberg, 1884, from Brazil, Argentina, Ecuador, Peru, Bolivia and Chile are described: $M$. albinoi, $M$. aliceae, $M$. amazonica, $M$. aurea, $M$. bahiana, $M$. boliviana, $M$. buzzii, $M$. cacerensis, $M$. carinata, $M$. catamarcensis, $M$. chilena, M. clypeata, M. ecuatoriana, M. grafi, M. hirsutula, M. larocai, M. marinonii, M. mielkei, $M$. mirnae, $M$. montanicola, $M$. moureana, $M$. ornata, $M$. paranaensis, $M$. plumata, $M$. renatoi, $M$. sertanicola, $M$. setigera, $M$. sexcincta, $M$. solangeae, $M$. trifasciata and $M$. villosa. Two species are revalidated: Melissoptila argentina Brèthes, 1910 and Melissoptila ochromelaena (Moure, 1943). A key to the South American species is proposed to include the new species and the twenty one known species that belong to this genus.

KEY WORDS. Melissoptila, Anthophoridae, Hymenoptera, Taxonomy, new species.
\end{abstract}

Proposto por Holmberg (1884), Melissoptila é um gênero de Eucerini de ampla distribuição geográfica, ocorre desde o rio Grande, na fronteira dos Estados Unidos com o México, até a Patagônia no sul da Argentina. O estudo dos espécimens depositados na Coleção de Entomologia Pe. J.S. Moure e de abelhas recebidas para identificação, levou à descrição de 31 espécies sulamericanas, não foram examinadas as espécies da América Central. Na revisão de Melissoptila feita por URBAN (1968), lamentavelmente uma publicação de má qualidade, com páginas em branco, frases truncadas ou incompreensíveis e infindáveis êrros tipográficos, a autora considerou discutíveis, porém manteve os três sub-gêneros relacionados por MOURE \& MiCHENER (1955). Neste trabalho os sub-gêneros foram suprimidos porque as fêmeas não apresentam caracteres que as diferenciem em grupos de espécies; e os machos, apenas de quatro espécies, apresentam especializações peculiares nas pernas o que levaria à proposta de mais um sub-gênero, para M. paranaensis sp.n., resultando dois sub-gêneros monotípicos, um com duas espécies, e um quarto sub-gênero com 48 espécies.

1) Contribuição número 977 do Departamento de Zoologia, Universidade Federal do Paraná.

2) Departamento de Zoologia, Universidade Federal do Paraná. Caixa Postal 19020, 81531-990 Curitiba, Paraná, Brasil. Bolsista do CNPq. 


\section{MATERIAL E MÉTODOS}

O material estudado e os tipos estão depositados na Coleção de Entomologia Pe. J.S. Moure, do Departamento de Zoologia da Universidade Federal do Paraná, Brasil (DZUP); no Laboratório de Pesquisas Biológicas da Pontifícia Universidade Católica do Rio Grande do Sul, Brasil (PUCRS); e no American Museum of Natural History, New York, USA (AMNH).

Todas as medidas são dadas em milímetros; a distância interorbital superior e a inferior foram obtidas nos extremos do bordo reto das órbitas internas; os flagelômeros dos machos foram medidos no maior comprimento, ou largura.

Foram desenhados o sétimo e o oitavo esternos e a espata da genitália dos machos de quase todas as espécies estudadas, para dirimir dúvidas e auxiliar na identificação. Os exemplares foram colocados em câmara úmida e posteriormente foi feita a dissecção com um micro-alfinete de ponta dobrada.

Os pêlos decumbentes modificados da face ventral dos mesepisternos dos machos, que formam uma área distinta da pilosidade adjacente, foram interpretados como espatulado-longos quando a parte basal cilíndrica e tão longa como duas vezes a parte distal, esta quase reta na ponta, e com ramificações largas e achatadas; espatulado-curtos, com a parte basal quase igualando a distal, de contorno levemente aredondado, e com ramificações largas e achatadas; lanceolados, quando distintamente mais largos que os pêlos das vizinhanças, com ramificações curtas e largas também para a base. Nas fêmeas foram constatados pêlos ramificados na face ventral dos mesepisternos, ou cerdas finas lisas eretas de ápice reto ou arqueado na ponta.

A área basal do propódeo foi considerada estreitamente grosso-pontuada quando tão larga como um diâmetro de ocelo e largamente grosso-pontuada quando igual ou mais larga que dois diâmetros de ocelo.

A distribuição geográfica das espécies foi colocada na chave para a identificação das fêmeas; quando somente o macho foi descrito, a distribuição geográfica consta na respectiva chave.

\section{DESCRIÇÕES}

\section{Melissoptila amazonica sp.n.}

Figs $1,14,21,41,60$

Macho com área amarela trilobulada no clípeo; face ventral dos mesepisternos com pêlos espatulado-curtos.

Holótipo macho. Tegumento preto; amarelo no labro, metade basal das mandíbulas e larga área trilobulada no clípeo. Tégula e tarsômeros castanhos. Margens translúcidas castanhas nos tergos, branco-amareladas nos esternos.

Pilosidade branca na cabeça; enegrecida no mesoscuto e escutelo; branca no propódeo, pernas e face lateral dos mesepisternos; na face ventral dos mesepisternos castanho-esbranquiçada; cerdas fulvo-amareladas no lado ventral dos basitarsos e nos tarsômeros distais. Preta no disco do primeiro tergo, com faixas brancas látero-apicais; do segundo ao quinto tergo preta na base e branca na margem, esta mais larga no quinto; enegrecida nos demais tergos; branca nos esternos basais, amarelada no quarto e quinto esternos. 

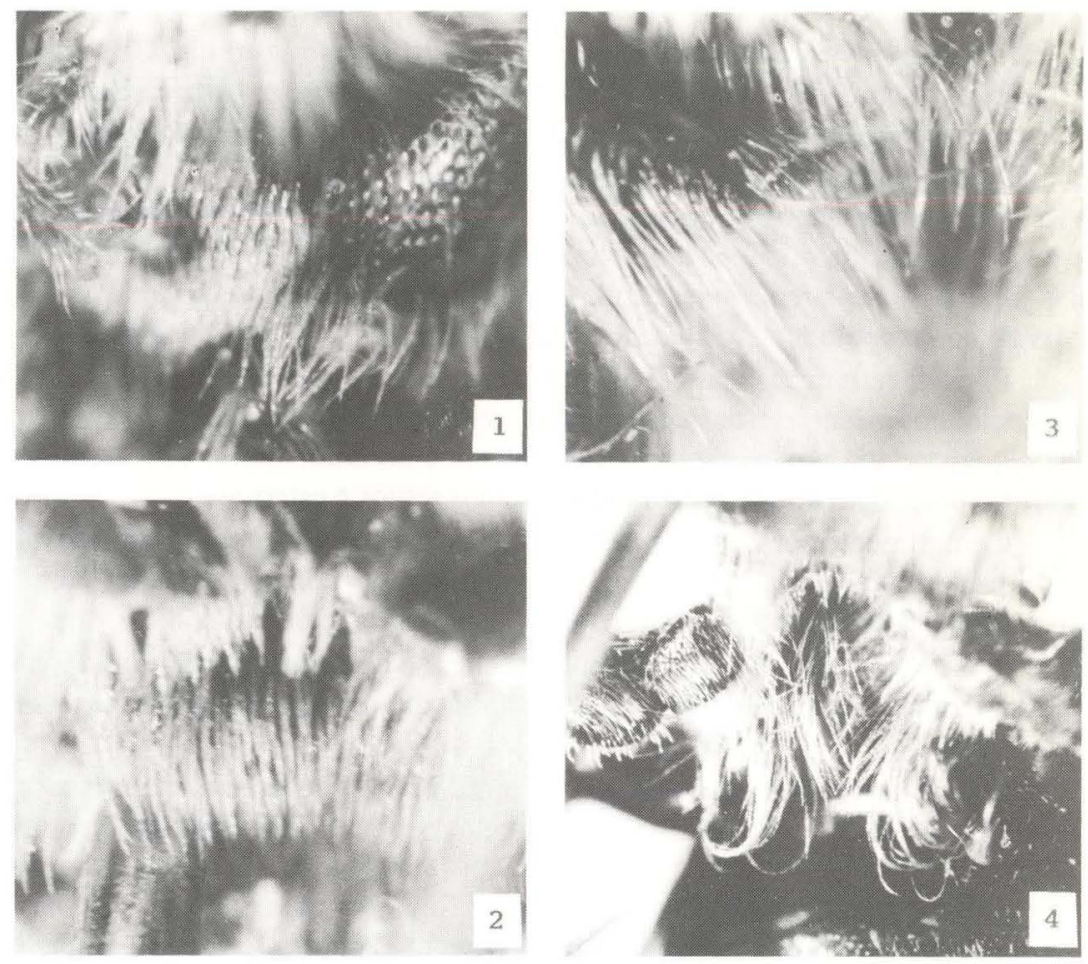

Figuras 1-4. (1) Melissoptila amazonica e (2) M. grafi, face ventral dos mesepisternos do macho; (3) M.marinonii, face ventral dos mesepisternos da fêmea e cerdas lisas da base das pernas anteriores; (4) $M$. setigera, trocanteres e base dos fêmures medianos, e trocanteres posteriores da fêmea.

Comprimento aproximado 8,67; largura da cabeça 2,88; comprimento do olho 1,60; distância interorbital superior 1,72 e a inferior 1,48; comprimento dos flagelômeros basais 0,$26 ; 0,54 ; 0,46$; diâmetro do segundo flagelômero 0,24.

Holótipo macho. BrasiL, Amazonas: Tefé, XII.61, F. M. Oliveira leg. Dois parátipos, machos, com a mesma etiqueta de procedência. Depositados na Coleção Pe. J.S. Moure (DZUP).

Distribuição geográfica. Brasil: Amazonas.

Etimologia. O nome alusivo à região em que foram coletados os exemplares.

\section{Melissoptila albinoi sp.n.}

Figs $20,40,60$

Melissoptila (Ptilomelissa) pubescens; Urban, 1968: 71 (partim).

Macho com pêlos plumosos finos na área ventral nos mesepisternos; primeiro flagelômero maior que a metade do segundo; clípeo micro-reticulado e densopontuado com carena médio-basal. Fêmea com clípeo em parte micro-reticulado, 
paroculares superiores sem área brilhante, quase foscas junto às órbitas. Esta espécie e $M$. sexcincta sp.n. são simpátricas. Melissoptila sexcincta é caracterizada pelos trocânteres medianos dos machos densamente revestidos com pêlos espatulado-curtos e pelas faixas pilosas escuras na base dos tergos.

Holótipo macho. Tegumento predominante preto; mandíbulas quase inteiramente amarelas, labro e clípeo amarelos, clípeo com duas nódoas pequenas enegrecidas junto às fóveas tentoriais, tégulas castanho-amareladas, mediotarsos e distitarsos de um amarelo levemente acastanhado, margem dos tergos enegrecida.

Pilosidade branco-amarelada na cabeça, amarela no dorso do mesosoma e adjacências dos mesepisternos, restante dos mesepisternos e grande parte das pernas brancos, amarelada nos mediotarsos, distitarsos e no lado ventral dos basitarsos; branca no propódeo; amarelo-esbranquiçada nos tergos e esternos.

Comprimento aproximado 10,5; largura da cabeça 3,3; comprimento do olho 1,76; distância interorbital superior 2,16 e a inferior 1,60; comprimento dos flagelômeros basais: 0,$36 ; 0,58 ; 0,50$; diâmetro do segundo flagelômero 0,22 .

Alótipo. Tegumento preto, amarelo na base e disco das mandíbulas, tégulas enegrecidas, mediotarsos e distitarsos castanho-amarelados, primeiro tergo sem margem clara.

Pilosidade branco-amarelada na cabeça, castanho-enegrecida no mesoscuto e escutelo, mesoscuto com pêlos amarelo-palha na base, metanoto ocráceo com pêlos enegrecidos de permeio; propódeo, mesepisternos e artículos basais das pernas brancos, tíbias e basitarsos posteriores amarelo-fulvos no lado externo, tarsômeros anteriores e medianos esbranquiçados, cerdas ventrais dos basitarsos fulvo-alaranjadas; amarelo-esbranquiçada nos tergos; segundo ao quarto esterno com franja apical branca e cerdas amarelo-fulvas no restante.

Comprimento aproximado 9,33; largura da cabeça 3,58; comprimento do olho 1,96; distância interorbital superior 2,33 e a inferior 2,0.

Holótipo macho. ArgentinA, Catamarca: Águas de las Palomas, 26.II.74, J.L. Neff leg. Alótipo com a mesma etiqueta de procedência. Depositados na Coleção Pe. J.S. Moure (DZUP).

Distribuição geográfica. Argentina: Catamarca.

Etimologia. Em homenagem ao Prof. Albino M. Sakakibara (DZUP).

\section{Melissoptila aliceae sp.n.}

Fig. 60

Fêmea com faixa subapical amarela no clípeo, tergos com pilosidade amarelada, paroculares superiores com área micro-reticulada porém brilhante; base do propódeo com faixa grosso-pontuada larga; tíbias e basitarsos posteriores com cerdas ramificadas, cerca de cinco ramos a cada lado. Esta espécie, M. plumata sp.n. e $M$. solangeae sp.n. são simpátricas; entretanto, sendo conhecida somente a fêmea, M. plumata distingue-se pelas cerdas multi-ramificadas das tíbias e basitarsos posteriores; $M$. solangeae, pelo clípeo inteiramente preto e largas áreas lisas, sem micro-reticulação nas paroculares superiores. 

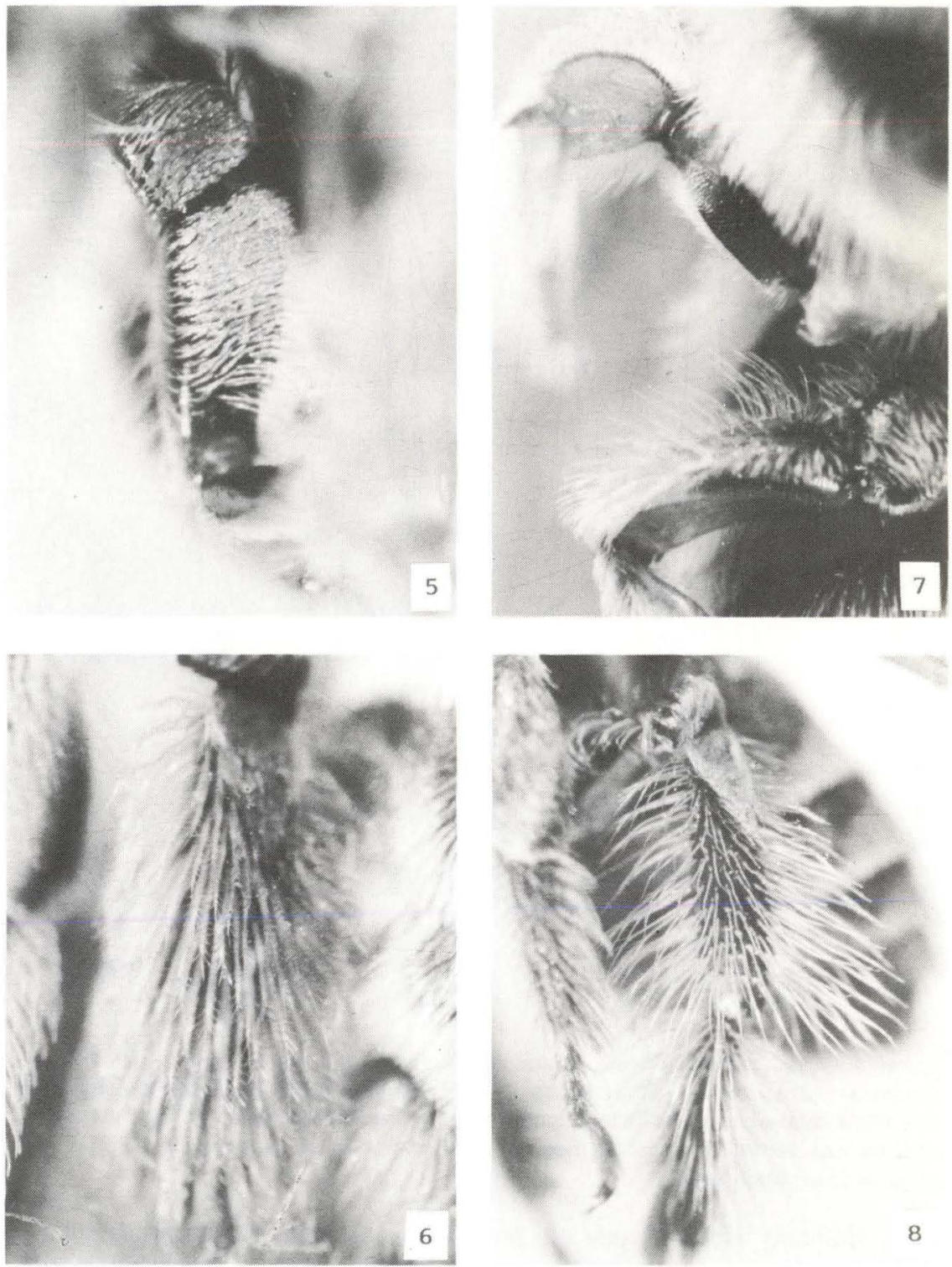

Figuras 5-8. (5) Melissoptila cacerensis, face anterior do trocanter e do fêmur medianos do macho; (6) M. plumata, tíbia posterior da fêmea; (7) M. paranaensis, fêmur e tíbia medianos, e trocanter e fêmur posteriores do macho; (8) $M$. setigera, tibia e basitarso posteriores da fêmea. 

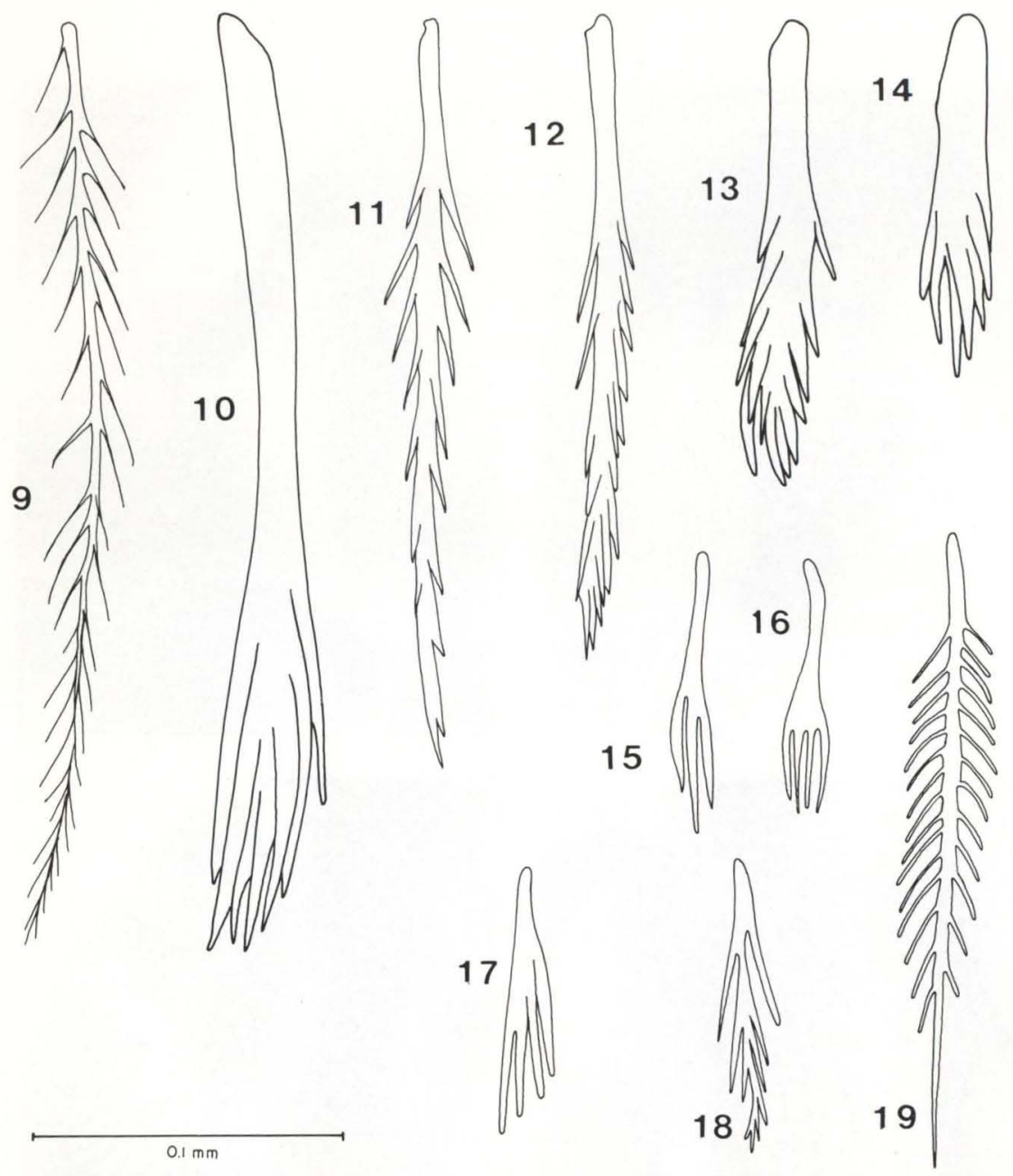

Figuras 9-19. (9-14) Pêlos da face ventral dos mesepisternos dos machos. (9) Melissoptila moureana; (10) M. mielkei; (11) M. larocai; (12) M. carinata; (13) M. grafi; (14) M. amazonica. (15 e 16) M. cacerensis, pêlos da face ventral do fêmur mediano do macho; (17 e 18) M. villosa, pêlos da face ventral do trocanter mediano do macho; (19) $M$. paranaensis, pêlo da faixa marginal do segundo tergo.

Holótipo fêmea. Tegumento preto com larga faixa subapical amarela no clípeo, mandíbulas com amarelo no terço basal e mancha alongada subapical amarelo-fulva. Tégulas, mediotarsos e distitarsos amarelo-fulvos. Margem translúcida castanha no primeiro tergo.

Pilosidade branca na cabeça, amarelada no vértice. Amarelo-fulva no mesoscuto e escutelo, branca no propódeo e mesepisternos, amarelada junto às asas; branca nas pernas; o lado externo das tíbias e dos basitarsos castanho-claro, nas pernas posteriores com cerdas brancas na parte anterior da face dorsal das tíbias e 
basitarsos, estes com as cerdas ventrais amarelo-fulvas. Amarelo-esbranquiçada nos tergos e nos esternos, no tergo distal acastanhada; franjas apicais brancas nos esternos.

Comprimento aproximado 7,83; largura da cabeça 3,$0 ;$ comprimento do olho 1,68; distância interorbital superior 1,80 e a inferior 1,64.

Holótipo fêmea. Brasil, Rio de Janeiro: Itatiaia 400m, 1.VIII.1975, W. Zikán leg. Parátipos: uma fêmea com a mesma etiqueta do holótipo; Mato Grosso: Três Lagoas, VIII.65 R. Zucchi leg. uma fêmea; Paraiba: Santo André, 21.XI.1955 [coletor anônimo] uma fềmea; Bahia: Maracás, 18.VIII.64, C. Elias leg. uma fềmea. Depositados na Coleção Pe. J.S. Moure (DZUP).

Distribuição geográfica. Brasil: Paraíba, Bahia, Mato Grosso, Rio de Janeiro.

Etimologia. Dedicada à Profa. Alice Fumi Kumagai, do Departamento de Zoologia da Universidade Federal de Minas Gerais.

\section{Melissoptila aurea sp.n.}

Figs $22,42,60$

Base do propódeo com larga faixa grosso-pontuada. Macho com pêlos plumosos na área ventral dos mesepisternos. Fêmea com cerdas castanho-claras no lado externo das tíbias; paroculares superiores micro-reticuladas e sem pontos grandes em estreita área junto às órbitas. Esta espécie, M. ecuatoriana sp.n. e $M$. pacifica (Cockerell, 1914) são simpátricas e apresentam um mesmo padrão de pilosidade; o macho de M. ecuatoriana distingue-se pelo clípeo amarelo com orla preta junto à sutura epistomal e a fêmea pelo tegumento largamente fosco nas paroculares superiores; em $M$. pacifica, a base do propódeo é estreitamente grossopontuada, a fêmea tem cerdas esbranquiçadas nas tíbias posteriores e larga área brilhante, sem micro-reticulação, nas paroculares superiores.

Holótipo macho. Tegumento preto com labro e clípeo amarelos, clípeo com duas nódoas pequenas pretas junto às fóveas tentoriais, unidas ao tegumento preto das paroculares (arredondadas e com a margem discal em arco); mandíbulas com grande área amarela no terço basal. Tégulas castanhas; tarsômeros castanho-amarelados, de um tom mais escuro nos basitarsos. Margem translúcida estreita castanho-amarelada nos esternos, mais larga e castanha no primeiro tergo.

Pilosidade branca na cabeça, os pêlos levemente tingidos de fulvo no vértice. Castanha no mesoscuto e escutelo; amarelo-esbranquiçada nos lados e nos cantos anteriores do mesoscuto, no metanoto, propódeo e mesepisternos; branca na área ventral dos mesepisternos; branca nos artículos basais das pernas, tíbias e tarsos branco-amarelados. Amarelo-dourada nos tergos; de um tom mais pálido nos esternos.

Comprimento aproximado 8,33; largura da cabeça 3,04; comprimento do olho 1,76; distância interorbital superior 1,88 e a inferior 1,40; comprimento dos flagelômeros basais 0,$28 ; 0,50 ; 0,42$; diâmetro do segundo flagelômero 0,24 . 

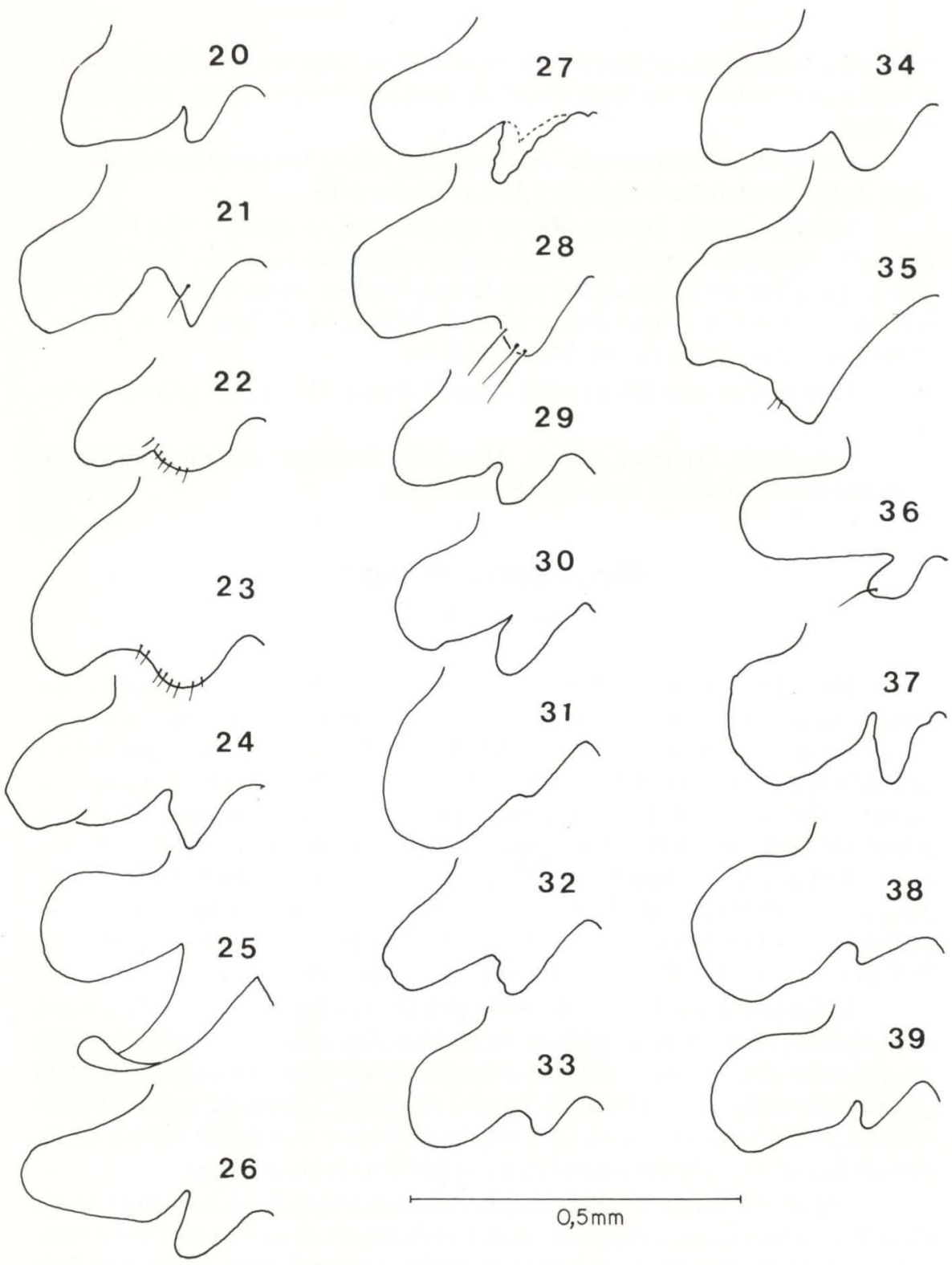

Figuras 20-39. Sétimo esterno dos machos de Melissoptila, metade distal. (20) M. albinoi; (21) M. amazonica; (22) M. aurea; (23) M. bahiana; (24) M. chilena; (25) M. catamarcensis; (26) M.carinata; (27) M.cacerensis; (28) M. clypeata; (29) M.ecuatoriana; (30) M. grafi; (31) M.larocai; (32) M. montanicola; (33) M. mielkei; (34) M. moureana; (35) M. paranaensis; (36) M. renato; (37) M. sertanicola; (38) M. sexcincta; (39) M. villosa. Somente a fig.20 com o apódema basal. 
Alótipo. Tegumento preto com longa mancha amarela subapical nas mandíbulas, ocupando mais da metade do seu comprimento. Tégulas castanhas; pernas com os tarsômeros castanho-amarelados. Tergo basal com larga margem translúcida castanha.

Pilosidade branca na cabeça, castanha nas paroculares superiores, parte da fronte e vértice. Castanha em quase todo o dorso do mesosoma, com poucos pêlos brancos na base do mesoscuto, branca no propódeo e mesepisternos; branca nos artículos basais das pernas, amarelo-esbranquiçada nas tíbias e tarsos, as tíbias anteriores e medianas com pêlos castanho-esbranquiçados no ápice, e as tíbias posteriores com cerdas castanhas formando uma estria a partir da placa basitibial; também com algumas cerdas castanhas nos basitarsos posteriores; cerdas ventrais dos basitarsos amarelas. Branco-amarelada nos tergos, acastanhada em parte do tergo distal; branca nas franjas apicais dos esternos.

Comprimento aproximado 7,83; largura da cabeça 3,0; comprimento do olho 1,70; distância interorbital superior 1,80 e a inferior 1,74 .

Holótipo macho. Equador, Loja: San Pedro, 8.IV.1965, L.E. Peña leg. Alótipo e um parátipo macho com a mesma etiqueta de procedência; depositados na Coleção Pe. J.S. Moure (DZUP). Quatro parátipos, machos, com a mesma etiqueta, depositados na Coleção de Entomologia (AMNH).

Distribuição geográfica. Equador: Loja.

Etimologia. Nome alusivo ao colorido da pilosidade.

\section{Melissoptila bahiana sp.n.}

Figs $32,43,60$

Face ventral dos mesepisternos dos machos com pêlos plumosos. Fêmeas com cerdas finas na face ventral dos mesepisternos; trocanteres anteriores, face anterior das tíbias e basitarsos posteriores com cerdas lisas longas.

Holótipo macho. Tegumento preto, com labro, clípeo e metade basal das mandíbulas amarelos, clípeo com duas nódoas negras junto às fóveas tentoriais. Tégulas castanhas, tarsômeros castanho-claros. Tergos e esternos sem margem translúcida amarela.

Pilosidade branca na cabeça. Amarela no mesoscuto e escutelo, amarelada nos lobos pronotais e no metanoto, branca no propódeo e mesepisternos; branca nas pernas; cerdas ventrais dos basitarsos castanho-amareladas. Branca, com leve tonalidade castanha no primeiro tergo, com faixa apical castanho-escura; do segundo ao sexto tergo preta na base e com larga faixa castanha apical, com leve tonalidade bronzeada; no sétimo tergo enegrecida; esternos com franja apical curta cremosa e no restante pêlos e cerdas castanhos.

Comprimento aproximado 8,67; largura da cabeça 3,20; comprimento do olho 1,84; distância interorbital superior 1,92 e a inferior 1,54 ; comprimento dos flagelômeros basais 0,30; 0,56; 0.46; diâmetro do segundo flagelômero 0,22.

Alótipo. Tegumento preto, com mancha subapical amarela alongada nas mandíbulas. Tégulas castanhas; mediotarsos e distitarsos de um castanho claro. Tergos sem margem translúcida amarela, no primeiro larga margem translúcida castanha. 

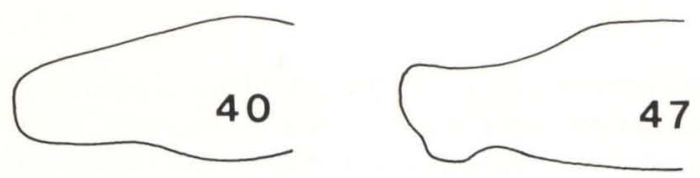

53
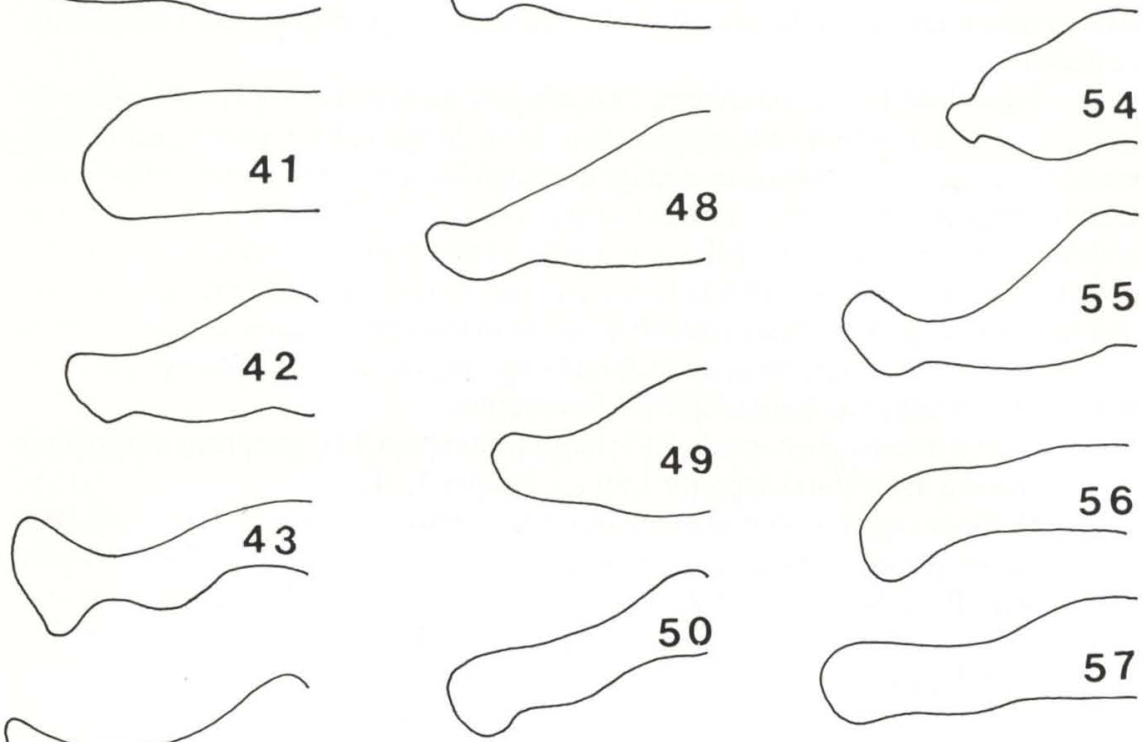

54
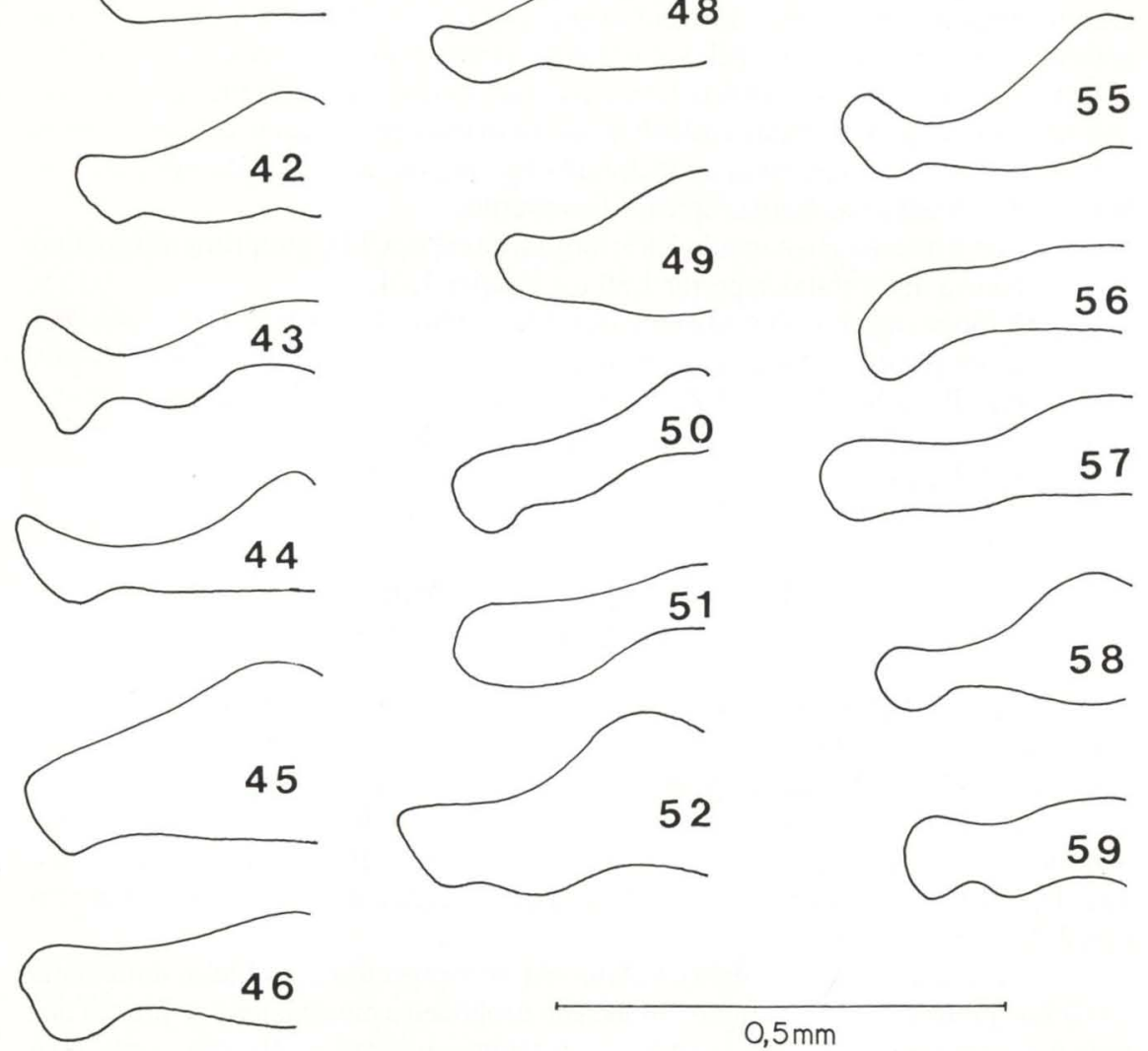

\section{$0,5 \mathrm{~mm}$}

Figuras 40-59. Espata da genitália dos machos de Melissoptila. (40) M.albinoi; (41) $M$. amazonica; (42) $M$. aurea; (43) $M$. bahiana; (44) $M$. cacerensis; (45) $M$. carinata; (46) $M$. catamarcensis; (47) M. chilena; (48) M. clypeata; (49) M. ecuatoriana; (50) M. grafi; (51) $M$. larocai; (52) M. montanicola; (53) M. mielkei; (54) M. moureana; (55) M. paranaensis; (56) M. sertanicola; (57) M. sexcincta; (58) M. renatoi; (59) M. villosa.

Pilosidade branca na cabeça, mesclada com enegrecido nas paroculares superiores e fronte, enegrecida no vértice. Enegrecida em quase todo mesoscuto e escutelo, com pêlos brancos na base do mesoscuto; de um castanho-claro no metanoto, branca nos flancos do propódeo e mesepisternos; área ventral dos mesepisternos, coxas, trocanteres e fêmures anteriores e coxas medianas com cerdas 
longas amarelo-palha; tíbias e basitarsos anteriores e medianos enegrecidos, os posteriores com cerdas castanho-enegrecidas na face posterior; branca nos fêmures medianos e três artículos basais das pernas posteriores, com alguma mistura de castanho-claro nos fềmures medianos; cerdas amarelo-palha nas tíbias posteriores e em parte dos basitarsos posteriores. Castanha clara na base do primeiro tergo, com pequenas faixas laterais de um castanho-dourado e o ápice largamente glabro; do segundo ao quarto tergo preta na base e com larga faixa apical castanho-bronzeada, no quarto tergo em ângulo obtuso no meio; tergos apicais e esternos castanhos, com uma tonalidade muito mais pálida nas franjas apicais do segundo ao quarto esterno.

Comprimento aproximado 10,0; largura da cabeça 3,52; comprimento do olho 1,94; distância interorbital superior 2,20 e a inferior 1,98.

Variações. Faixa apical dos tergos dos machos, de amarelo-dourada a castanho-dourada com algo de bronzeado na base; nas fêmeas com as faixas castanho-amareladas ou muito escuras, pouco distintas da base enegrecida.

Holótipo macho. Brasil, Bahia: Jequié, 10.VIII.64, C. Elias leg. Alótipo, quatro parátipos, três machos e uma fêmea, com os mesmos dados de coleta do holótipo. Parátipos: Bahia: Itapetinga, 25.VII.1967, C. Elias leg. uma fêmea; Espirito Santo: Santa Teresa, 6.VI.1964, C. Elias leg. um macho e uma fêmea; Afonso Claudio, 14.VII.1966, C.T. \& C. Elias leg. uma fêmea; São João Petrópolis, 27.VI.1964, 1 a 8.VI.1966, C. Elias leg. 2 fêmeas; Minas Gerais: Aimorés, 15 a 18.VI.1966, C. Elias leg. uma fềmea. Depositados na Coleção Pe. J.S. Moure (DZUP).

Distribuição geográfica. Brasil: Bahia, Minas Gerais, Espírito Santo.

Etimologia. Nome alusivo ao estado da Bahia, onde foram coletados os primeiro exemplares estudados.

\section{Melissoptila boliviana sp.n.}

Fig. 60

Melissoptila (Ptilomelissa) thoracica; Urban, 1968: 77 (partim).

Fêmea com margem quase glabra no meio do segundo tergo, esternos com franjas castanhas e longas. Difere de $M$. tandilensis Holmberg, 1884, pela ausência de faixas brancas nos tergos, e de M. thoracica (Smith, 1854) pelo tamanho maior e ausência de franjas brancas nos esternos.

Holótipo fêmea. Tegumento preto, lado ventral do terceiro ao sétimo flagelômero castanho-amarelado. Tégulas amarelo-fulvas, translúcidas; mediotarsos e distitarsos castanho-amarelados. Tergos e esternos sem área translúcida clara.

Pilosidade branca na cabeça, branco-amarelada no vértice, dorso do mesosoma e metade basal dos mesepisternos, castanha no propódeo; pernas amarelo-palha nos artículos basais e com castanho nas tíbias e tarsos, levemente amarelada nas tíbias e lado externo dos basitarsos posteriores com uma estria de cerdas castanhas partindo da placa basitibial; cerdas castanhas no lado ventral dos basitarsos. Castanha na base e preta nos flancos do primeiro tergo, nos demais tergos e nos esternos preta, estes com franja apical castanha. 
Comprimento aproximado 12,83; largura da cabeça 4,28; comprimento do olho 2,24; distância interorbital superior 2,94 e a inferior 2,44

Holótipo fêmea. Bolivia, Oruro: (3.800m) IV.62, F.H. Walz leg. Depositado na Coleção Pe. J.S. Moure (DZUP).

Distribuição geográfica. Bolivia: Oruro.

Etimologia. Nome alusivo ao país em que foi coletado o holótipo.

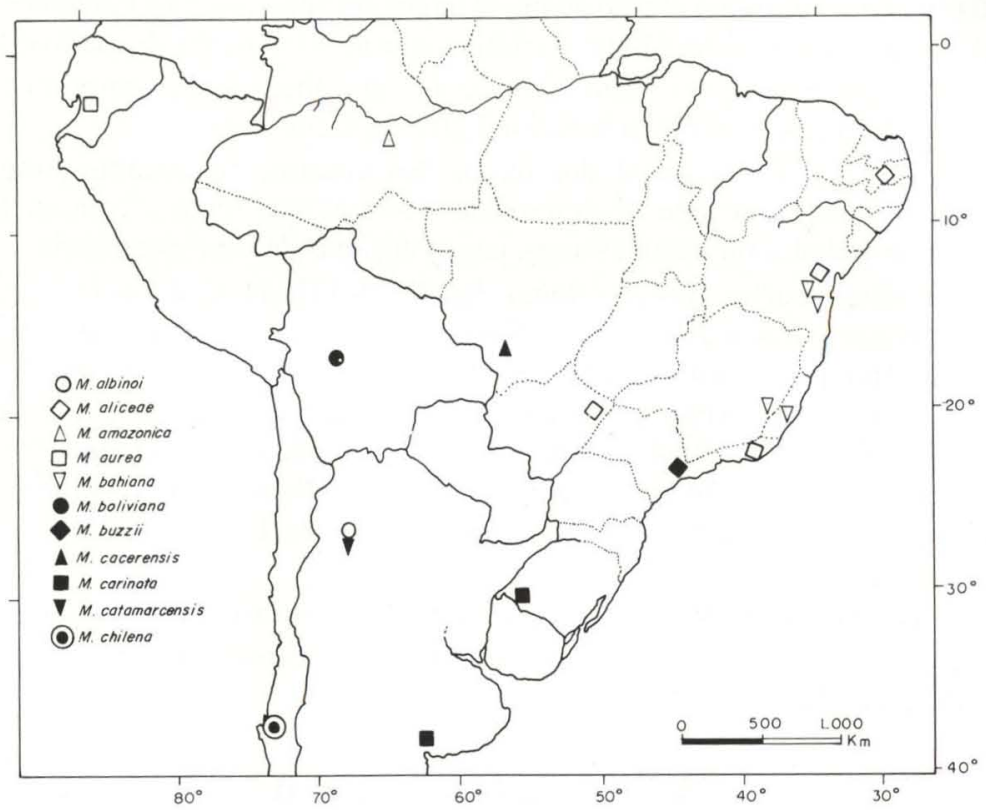

Figura 60. Mapa com a distribuição geográfica das espécies de Melissoptila.

\section{Melissoptila buzzii sp.n.}

Fig. 60

Fêmea com cerdas lisas pretas nas escopas tibial e basitarsal; cerdas finas lisas na face ventral dos mesepisternos. Macho com mescla de branco e enegrecido na parte lateral dos mesepisternos e pêlos plumosos na face ventral.

Holótipo fêmea. Tegumento preto; mediotarsos e distitarsos castanho-enegrecidos. Tergos sem orla translúcida clara, esternos com margem translúcida esbranquiçada.

Pilosidade esbranquiçada no clípeo, paroculares inferiores e genas, acastanhada no labro, castanha clara nas paroculares superiores e enegrecida no vértice. Mesoscuto, escutelo e metanoto pretos, sem áreas brancas; mesepisternos com as cerdas ventrais e os pêlos da face lateral esbranquiçados, os lobos pronotais e adjacências dos mesepisternos castanhos com mescla de branco; coxas, trocanteres 
e fêmures amarelo-palha, tíbias e basitarsos enegrecidos, tarsômeros distais acastanhados, cerdas ventrais dos basitarsos castanhas, com uma tonalidade mais arruivada nos posteriores. Branca na base, castanho-clara no disco e nos cantos do primeiro tergo, distalmente amarelo-dourada e também desta cor nos demais tergos, escurecendo um pouco para a base; amarelada no disco dos esternos, branca nas franjas apicais e amarelo-fulva nos esternos apicais.

Comprimento aproximado 10,83; largura da cabeça 4,0; comprimento do olho 2,08; distância interorbital superior 2,42 e a inferior 2,25.

Alótipo. Tegumento preto; amarelo claro no labro e clípeo, com duas pequenas nódoas negras próximas às fóveas tentoriais no clípeo, mandíbulas com grande área basal amarela. Tarsos acastanhados. Tergos castanho-enegrecidos, sem orla translúcida clara.

Pilosidade branca em grande parte da cabeça, castanho-enegrecida atrás dos ocelos. Mesoscuto, escutelo e metanoto enegrecidos, mesepisternos brancos ventralmente, com mescla de branco e enegrecido na face lateral; pernas brancas, tíbias e basitarsos posteriores castanhos no lado externo. Tergo basal branco-acastanhado, demais tergos com pêlos amarelo-dourados; esternos com franjas apicais brancas curtas e pêlos castanhos no disco.

Comprimento aproximado 9,83; largura da cabeça 3,50; comprimento do olho 1,92; distância interorbital superior 2,17 e a inferior 1,67 ; comprimento dos três flagelômeros basais 0,38; 0,64; 0,54; diâmetro do segundo flagelômero 0,22.

Holótipo fêmea. Brasil, São Paulo: Campos do Jordão, 24.II.90, M. Gimenes leg. Alótipo e um parátipo fêmea com a mesma procedência, o alótipo coletado em 27.IV.90 e o parátipo em 18.III.90. Depositados na Coleção Pe. J.S. Moure (DZUP).

Distribuição geográfica. Brasil: São Paulo.

Etimologia. Espécie dedicada ao Prof. Zundir J. Buzzi (DZUP).

\section{Melissoptila cacerensis sp.n.}

Figs $5,15,16,27,44,60$

Mesepisternos dos machos com pêlos plumosos; trocanteres e metade basal dos fêmures medianos com pêlos espatulado-curtos, decumbentes na face ventral.

Holótipo macho. Tegumento preto, com labro, metade basal das mandíbulas e clípeo amarelos, êste com duas nódoas pretas próximas às fóveas tentoriais. Tégulas castanho-amareladas, pernas também desta cor a partir do ápice das tíbias até o tarsômero distal. Margem translúcida amarela larga nos tergos e mais estreita nos esternos.

Pilosidade branco-amarelada na cabeça e dorso do mesosoma; branca nos mesepisternos e pernas, pêlos espatulado-curtos dos trocanteres e base dos fêmures medianos levemente castanho-amarelados, cerdas ventrais dos basitarsos também desta cor. Amarelada nos tergos e esternos.

Comprimento aproximado 7,67; largura da cabeça 3,32; comprimento do olho 1,92; distância interorbital superior 2,16 e a inferior 1,60; comprimento dos três flagelômeros basais 0,$30 ; 0,60 ; 0,46$; diâmetro do segundo flagelômero 0,18 .

Holótipo macho. Brasil, Mato Grosso: Cáceres, 19.X.61, F.M. Oliveiraleg. 
Três parátipos, machos, com a mesma etiqueta de procedência. Depositados na Coleção Pe. J.S. Moure (DZUP).

Distribuição geográfica: Brasil: Mato Grosso.

Etimologia. Nome alusivo à localidade onde foram coletados os exemplares.

\section{Melissoptila carinata sp.n.}

Figs $12,26,45,60$

Melissoptila (Ptilomelissa) pubescens; Urban, 1968: 71 (partim).

Macho com pêlos lanceolados na face ventral dos mesepisternos; sexto esterno com carenas curtas afastadas do bordo e formando um semi-círculo a cada lado. Fêmea com cerdas finas na face ventral dos mesepisternos.

Holótipo macho. Tegumento preto, com labro e clípeo amarelos; clípeo com duas nódoas pretas junto às fóveas tentoriais; mandíbulas amarelas no terço basal, com mancha subapical alongada também amarela. Tégulas castanhas; pernas com o ápice do fềmur, tíbia e tarso castanho-amarelados. Margem translúcida amarela estreita nos tergos e esternos.

Pilosidade branca na cabeça. Branca no mesosoma porém com pêlos castanhos no terço apical do mesoscuto e no disco do escutelo; branca nas pernas, com cerdas amarelo-fulvas no lado ventral dos basitarsos. Amarelada nos tergos e esternos.

Comprimento aproximado 8,33; largura da cabeça 3,36; comprimento do olho 2,0; distância interorbital superior $2,12 \mathrm{e} \mathrm{a} \mathrm{inferior} 1,72$; comprimento dos três flagelômeros basais 0,$24 ; 0,46 ; 0,38$; diâmetro do segundo flagelômero 0,22 .

Alótipo. Tegumento preto com grande área amarela no terço basal das mandíbulas. Tégulas castanhas; pernas castanhas com os tarsômeros castanho-amarelados. Primeiro tergo com margem translúcida amarelada.

Pilosidade branca na cabeça. Castanho-clara no disco do mesoscuto e no escutelo, branca no restante do mesosoma exceto as cerdas lisas amareladas na área ventral dos mesepisternos; pernas com o branco predominando, com pêlos amarelo-fulvos na parte distal das tíbias anteriores e na metade apical das medianas, amarelados nas tíbias e basitarsos posteriores; cerdas ventrais dos basitarsos amarelo-fulvas. Amarelada nos tergos, inclusive no terço distal do primeiro, acastanhada no sexto tergo; esternos com cerdas semi-eretas amarelo-fulvas e franjas apicais brancas.

Comprimento aproximado 9,0; largura da cabeça 3,56; comprimento do olho 2,0; distância interorbital superior 2,28 e a inferior 1,94 .

Holótipo macho. ARgentinA, Buenos Aires: Felipe Sola, I.1952, A. Martinez leg. Alótipo e quatro parátipos machos, com a mesma procedência do holótipo; XII.1952 uma fêmea; XII.1953 duas fêmeas; Buenos Aires: Tornquist, XII.1954, F.Walz leg. três parátipos, machos. Brasil, Rio Grande do Sul: Alegrete, 25.XI.1985, Wittmann leg. uma fêmea. Depositados na Coleção Pe. J.S. Moure (DZUP).

Distribuição geográfica. Argentina: Buenos Aires; Brasil, Rio Grande do Sul. Etimologia. Nome alusivo às carenas do sexto esterno do macho. 


\section{Melissoptila catamarcensis sp.n.}

Figs $25,46,60$

Macho com pêlos plumosos na face ventral dos mesepisternos; fềmures medianos com pilosidade curta e decumbente, mais longa na base; segundo flagelômero cerca de três vezes o comprimento do primeiro; placas medianas do sétimo esterno tão longas como o comprimento do esterno na linha média.

Holótipo macho. Tegumento preto, labro e clípeo amarelos; clípeo com duas nódoas negras junto às fóveas tentoriais, unidas ao tegumento preto das paroculares; mandíbulas com o terço basal e uma mancha subapical alongada amarelos. Tégulas castanhas, translúcidas; pernas com tíbia e tarso amarelo-acastanhados. Tergos e esternos com larga margem translúcida amarela.

Pilosidade branca na cabeça, parte do mesosoma e pernas; amarelo-esbranquiçada no mesoscuto, escutelo, e cerdas ventrais dos basitarsos. Amarela nos tergos, mais pálida nos esternos, estes com franjas brancas apicais curtas.

Comprimento aproximado 9,17; largura da cabeça 3,32; comprimento do olho 1,88; distância interorbital superior 2,08 e a inferior 1,56; comprimento dos três flagelômeros basais 0,$21 ; 0,70 ; 0,58$; diâmetro do segundo flagelômero 0,26.

Holótipo macho. Argentina, Catamarca: Colpes, 19.X.73, J.L. Neff leg. Depositado na Coleção Pe. J.S. Moure (DZUP).

Distribuição geográfica. Argentina: Catamarca.

Etimologia. Nome alusivo à localidade em que foi coletado o holótipo.

\section{Melissoptila chilena sp.n.}

Figs $24,47,60$

Tíbias e basitarsos posteriores denso-pilosos tanto no macho como na fêmea. Macho com pêlos plumosos nos mesepisternos; segundo flagelômero pouco maior que o dôbro do primeiro. Fêmea com margem translúcida larga amarelada nos tergos; paroculares superiores com área levemente micro-reticulada larga e brilhante, chegando aos ocelos laterais, os pontos grandes e rasos.

Holótipo macho. Tegumento preto, labro e clípeo amarelos, clípeo com duas nódoas pequenas castanhas próximas às fóveas tentoriais; mandíbulas amarelas na metade basal, com mancha subapical também amarela. Tégulas castanhas; metade apical das tíbias e os tarsos castanho-amarelados. Tergos e esternos com larga margem translúcida amarela, nos esternos um pouco mais estreita.

Pilosidade branco-amarelada na cabeça. Amarela no mesoscuto, escutelo e face dorsal dos mesepisternos; branca na parte ventral do mesosoma e nas pernas; cerdas ventrais dos basitarsos amareladas. Amarela nos tergos, densa e longa quase até o ápice do tergo basal, branca nos esternos.

Comprimento aproximado 8,33; largura da cabeça 3,40; comprimento do olho 1,84; distância interorbital superior 2,12 e a inferior 1,60; comprimento dos três flagelômeros basais 0,$26 ; 0,56 ; 0,48$; diâmetro do segundo flagelômero 0,22 . 


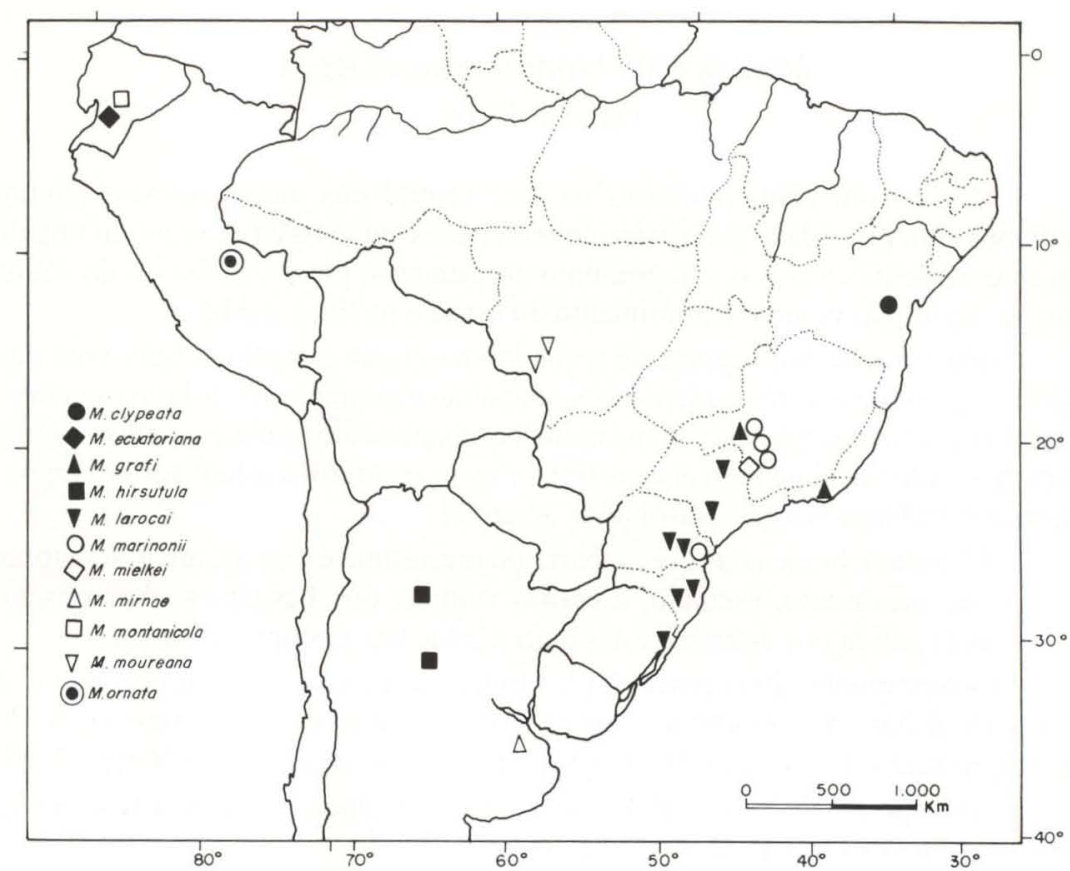

Figura 61. Mapa com a distribuição geográfica das espécies de Melissoptila.

Alótipo. Tegumento preto; mandíbulas com mancha amarela subapical ocupando mais da metade do seu comprimento e área basal castanho-amarelada. Tégulas castanhas, translúcidas, com mancha amarelada; pernas com os basitarsos enegrecidos, os mediotarsos e distitarsos castanho-amarelados. Tergo basal com margem translúcida amarela estreita.

Pilosidade branca na cabeça. Branca no mesosoma, amarelada no mesoscuto e escutelo; branca nos três artículos basais das pernas, nas anteriores e medianas predomina o branco nas tíbias, com pêlos fulvo-claros na área distal; basitarsos anteriores com mescla de branco e fulvo e os medianos brancos dorsalmente; tíbias e basitarsos posteriores com a escopa esbranquiçada, demais tarsômeros esbranquiçados; cerdas ventrais dos basitarsos amarelo-fulvas, de um tom mais castanho nas anteriores. Amarelo-palha nos tergos; esternos com cerdas amarelo-fulvas e franjas apicais brancas.

Comprimento aproximado 8,83; largura da cabeça 3,28; comprimento do olho 1,68; distância interorbital superior 2,12 e a inferior 1,80 .

Holótipo macho. CHILE, Coquimbo: Cerrillos Pobres, 7.III.56, L. Peña leg. . Alótipo e três parátipos machos com a mesma etiqueta do holótipo. Outros parátipos de Coquimbo: La Serena, 6.III.1950 uma fêmea; Santiago: Tobalaba, II.1956, L.E. Peña leg. uma fêmea. Depositados na Coleção Pe. J.S. Moure (DZUP).

Distribuição geográfica. Chile: Coquimbo, Santiago.

Etimologia. Nome alusivo ao país onde foram coletados os exemplares. 


\section{Melissoptila clypeata sp.n.}

Figs 28, 48, 61

Macho com pêlos plumosos na área ventral dos mesepisternos; clípeo com o tegumento fosco, micro-reticulado; base do propódeo com faixa grosso-pontuada larga. M. clypeata, e M. sertanicola são simpátricas; o macho destas duas espécies têm em comum larga faixa grosso-pontuada na base do propódeo porém diferem nas duas características citadas acima.

Holótipo macho. Tegumento preto, labro esbranquiçado, clípeo amarelo com duas nódoas enegrecidas perto das fóveas tentoriais, mandíbulas com a metade basal amarela e mancha alongada subapical também amarela. Tégulas, mediotarsos e distitarsos castanho-amarelados. Tergo basal com área translúcida castanho-escura.

Pilosidade branca na cabeça, amarela pálida nas paroculares superiores e com um banho de fulvo no vértice. Amarelo-fulva no mesoscuto, escutelo e nos lobos pronotais; amarelo-palha no propódeo, face lateral dos mesepisternos, tíbias e tarsos; branca nos artículos basais das pernas, cerdas ventrais dos basitarsos amarelo-fulvas. Amarelo-dourada nos tergos, também no disco e margem do basal; amarelo-fulva nos esternos, franjas amarelas.

Comprimento aproximado 9,67; largura da cabeça 3,24; comprimento do olho 1,80; distância interorbital superior 1,92 e a inferior 1,60; comprimento dos três flagelômeros basais 0,$24 ; 0,66 ; 0,56$; diâmetro do segundo flagelômero 0,24 .

Holótipo macho. BrasiL, Bahia: Maracás, IX.65, F.M. Oliveira leg. Depositado na Coleção Pe. J.S. Moure (DZUP).

Distribuição geográfica. Brasil: Bahia.

Etimologia. Nome alusivo ao aspecto do clípeo.

\section{Melissoptila ecuatoriana sp.n.}

Figs $29,49,61$

Macho com nódoa amarela triangular no disco do clípeo, orlada com preto; mesepisternos com pêlos plumosos. Fêmea com grande área densamente micro-reticulada, fosca, nas paroculares superiores, deixando estria muito estreita brilhante junto às órbitas.

Holótipo macho. Tegumento preto, labro amarelo, clípeo amarelo com orla preta larga junto à sutura epistomal, mais larga nas proximidades das fóveas tentoriais resultando uma grande área amarela mais ou menos triangular; mandíbulas com nódoa basal amarela imperfeitamente dividida em duas. Tégulas e tarsômeros castanhos. Margem translúcida estreita castanho-amarelada no primeiro tergo, estreita e amarelada nos esternos.

Pilosidade branca na cabeça com pêlos castanhos atrás dos ocelos. Amarelo-acastanhada no mesoscuto e castanha no escutelo, branca no restante do mesosoma e nas pernas, com as cerdas ventrais dos basitarsos castanho-amareladas. Amarela nos tergos, o basal com o ápice glabro no meio, franjas laterais amarelas e subapicalmente com pêlos acastanhados; branca nos esternos, as cerdas discais amarelo-fulvas. 
Comprimento aproximado 8,33; largura da cabeça 2,88; comprimento do olho 1,60; distância interorbital superior 1,88 e a inferior 1,44; comprimento dos três flagelômeros basais 0,$20 ; 0,48 ; 0,40$; diâmetro do segundo flagelômero 0,20 .

Variações. Mesoscuto e escutelo castanho-pilosos.

Alótipo. Tegumento preto com mancha amarela alongada nas mandíbulas, ocupando mais da metade do seu comprimento. Tégulas castanhas; basitarsos enegrecidos, demais tarsômeros castanho-amarelados. Primeiro tergo com larga margem translúcida castanha, os demais com larga margem ferrugíneo-avermelhada.

Pilosidade branca na cabeça, pêlos castanhos atrás dos ocelos. Castanha no dorso do mesosoma, branca no propódeo e mesepisternos; pernas com os artículos basais brancos, tíbias e basitarsos amarelos, basitarsos anteriores com alguns pêlos castanhos de permeio, cerdas ventrais dos basitarsos amarelo-fulvas. Amarelo-dourada nos tergos e nas cerdas esternais, branca na base dos esternos e nas franjas.

Comprimento aproximado 8,67; largura da cabeça 3,28; comprimento do olho 1,86; distância interorbital superior 1,96 e a inferior 1,64.

Variações. Nódoa basal amarela das mandíbulas muito reduzida em alguns exemplares e ausente em outros. Quanto à pilosidade foi constatada a presença de pêlos brancos na base do mesoscuto.

Holótipo macho. Equador, Loja: San Pedro, 8.IV.1965, L.E. Peña leg. Alótipo e um parátipo macho com a mesma etiqueta de procedência; depositados na Coleção Pe. J.S. Moure (DZUP). Nove parátipos machos depositados na Coleção de Entomologia (AMNH).

Distribuição geográfica. Equador: Loja.

Etimologia. Nome alusivo ao país de origem dos exemplares estudados.

\section{Melissoptila grafi sp.n.}

Figs $2,13,30,50,61$

Fêmea sem franjas brancas nos esternos. Macho com pêlos lanceolados na área ventral dos mesepisternos, terceiro e quarto esternos com área glabra marginal medianamente.

Holótipo fêmea.Tegumento preto.

Pilosidade enegrecida na cabeça, branca nas genas e parte das paroculares. Todo o lado dorsal do mesosoma preto, ventralmente castanho-escuro, também desta cor em grande parte das pernas, incluindo os trocanteres posteriores; amarelo-acastanhado nas tíbias e basitarsos posteriores; cerdas ventrais dos basitarsos posteriores fulvo-acastanhadas, nos demais basitarsos enegrecidas. Tergo basal com pêlos brancos na base, segundo ao quarto tergo com margem larga branca e a base negra, demais tergos e esternos enegrecidos.

Comprimento aproximado 9,83; largura da cabeça 3,96; comprimento do olho 1,83; distância interorbital superior 2,25 e a inferior 2,08.

Alótipo. Tegumento preto com grande mancha amarela nas mandibulas; labro e clípeo amarelos, êste com duas pequenas nódoas pretas até as fóveas tentoriais. Tégulas e pernas enegrecidas. Sem margem pálida nos tergos. 
Pilosidade da cabeça enegrecida na fronte, paroculares e vértice, acastanhada no clípeo e branca no restante. Enegrecida no lado dorsal do mesosoma e nos lados dos mesepisternos, estes com pêlos esbranquiçados só na face ventral; pernas com pêlos brancos e enegrecidos, fềmures e tíbias medianos com pêlos enegrecidos; cerdas ventrais dos basitarsos fulvo-acastanhadas. Tergo basal com pêlos esbranquiçados só na base, restante enegrecido; do segundo ao quarto tergo com pêlos curtos enegrecidos na base e disco e faixa branca no ápice, sexto e sétimo tergos e os esternos enegrecidos.

Comprimento aproximado 8,33; largura da cabeça 3,33; comprimento do olho 1,92; distância interorbital superior 2,08 e a inferior 1,67; comprimento dos três flagelômeros basais 0,$36 ; 0,72 ; 0,56$; diâmetro do segundo flagelômero 0,20 .

Holótipo fêmea. Brasil, Rio de Janeiro: Rio de Janeiro (São Silvestre), 4.IV.1960, M. Alvarenga leg. Alótipo e dois parátipos, um macho e uma fêmea, com os mesmos dados do holótipo. Um parátipo, macho, de Minas Gerais: Sacramento, 26.III.1965, C.T. Elias leg. Depositados na Coleção Pe. J.S. Moure (DZUP).

Distribuição geográfica. Brasil: Minas Gerais, Rio de Janeiro.

Etimologia. Espécie dedicada ao Prof. Vinalto Graf (DZUP).

\section{Melissoptila hirsutula sp.n.}

Fig. 61

Fêmea com cerdas finas e arqueadas para trás nos esternos, cerdas finas nos trocanteres e fêmures anteriores, e na área ventral dos mesepisternos.

Holótipo fêmea. Tegumento preto com nódoa basal amarelada grande nas mandíbulas. Tégulas castanho-amareladas; pernas com as tíbias e tarsos castanhoamarelados. Tergo basal com larga margem castanha.

Pilosidade branca na cabeça com pêlos castanhos no vértice. Castanha no mesoscuto e escutelo, no mesoscuto com faixa basal de pêlos brancos; branca no propódeo, mesepisternos e lobos pronotais, branca nos artículos basais das pernas, amarelo-cremosa nas tíbias e tarsos, exceto os basitarsos anteriores castanhos inclusive nas cerdas ventrais; demais basitarsos com cerdas ventrais amarelo-fulvas. Amarela nos tergos; esternos com franjas apicais brancas e cerdas finas de cor creme levemente arqueadas para trás, amarelo-fulvas nos dois distais.

Comprimento aproximado 8,50; largura da cabeça 3,48; comprimento do olho 1,88; distância interorbital superior 2,20 e a inferior 1,84 .

Holótipo fêmea. ARGEnTina, Córdoba: Córdoba, 19.XI.1970, M.A. Fritz leg. Um parátipo, fêmea, da ARGENTINA, Santiago del Estero: $10 \mathrm{~km} \mathrm{~S} \mathrm{Rio} \mathrm{Hondo,}$ 30.X.1969, Pe. Moure \& Hurd leg. Depositados na Coleção Pe. J.S. Moure (DZUP). O holótipo sem o olho direito, parte adjacente da cabeça e parte dos flagelômeros, e só uma perna completa.

Distribuição geográfica. Argentina: Córdoba, Santiago del Estero.

Etimologia. Nome alusivo às cerdas dos esternos da fêmea. 


\section{Melissoptila larocai sp.n.}

Figs 11, 31, 51, 61

Melissoptila (Ptilomelissa) pubescens; Urban, 1968: 71 (partim).

Macho com pêlos lanceolados na face ventral dos mesepisternos; tíbias medianas com pilosidade esparsa e curta, fềmures medianos com pêlos curtíssimos. Fêmea com metade distal do disco do mesoscuto quase glabra com os pontos esparsos, e base do propódeo com estreita faixa grosso-pontuada.

Holótipo macho. Tegumento preto com labro e clípeo amarelos, clípeo com duas nódoas pretas próximas das fóveas tentoriais; mandíbulas com nódoa amarela grande no terço basal. Tégulas, tíbias e tarsos castanho-amarelados. Tergos com larga margem translúcida esbranquiçada, nos esternos um pouco mais estreita.

Pilosidade branca na cabeça e mesosoma, amarelo-fulva no mesoscuto e escutelo, com cerdas castanho-amareladas no lado ventral dos basitarsos. Tergo basal com faixa castanha estreita subapical e branca apical; do segundo ao quarto tergo enegrecido na base e com larga faixa apical branca; tergo distal castanho; branca nos esternos.

Comprimento aproximado 9,50; largura da cabeça 3,22; comprimento do olho 1,72; distância interorbital superior 2,0 e a inferior 1,71 ; comprimento dos três flagelômeros basais 0,$30 ; 0,36 ; 0,34$; diâmetro do segundo flagelômero 0,22.

Alótipo. Tegumento preto, tégulas e pernas castanho-enegrecidas, tergo basal com margem translúcida esbranquiçada.

Pilosidade branca na cabeça, com pêlos enegrecidos e amarelos no vértice. Amarela nos lobos pronotais e base do mesoscuto, restante do mesoscuto e escutelo castanhos, metanoto e propódeo brancos, mesepisternos e artículos basais das pernas brancos, restante das pernas amarelo, exceto o lado externo castanho-enegrecido nos basitarsos anteriores, tíbias e basitarsos medianos de um castanho claro; cerdas ventrais dos basitarsos fulvo-amareladas. Tergo basal amarelo nos flancos; do segundo ao quarto tergo enegrecido na base e largamente amarelo no ápice, as faixas amarelas mais estreitas só nos flancos e com o contorno basal reto no disco porém levemente anguloso no quarto tergo; quinto e sexto tergos com pêlos castanhos pálidos; do segundo ao quarto esterno com cerdas amarelo-fulvas semi-eretas ultrapassando o bordo, alongadas nos lados, franjas brancas ocultas sob as cerdas no terceiro e quarto esternos.

Comprimento aproximado 10,33; largura da cabeça 3,36; comprimento do olho 1,84; distância interorbital superior 2,16 e a inferior 1,90.

Variações nas fêmeas. Mancha subapical castanha obsoleta ou com leve banho de amarelo no clípeo. Quanto à pilosidade foi observada redução da área clara da base do mesoscuto e ocorrência de pêlos brancos em vez de amarelos nesta área; metanoto com mescla de preto ou inteiramente desta cor.

Holótipo macho. Brasil, São Paulo: Botucatu, X.1963, W. Zikán leg. Alótipo com a mesma etiqueta de procedência do holótipo. Parátipos, BrASIL, São Paulo: Batatais, II.1943, A. Stafuzza leg. uma fềmea; Paraná: Ponta Grossa (Vila Velha), 9.X.65, Mitchell e Graf leg. dois machos e uma fêmea; 2.XI.65, J.S. Moure 
leg. uma fêmea; Curitiba, 20.III.1944, J.S. Moure leg. uma fêmea; 24.XI.1981, J.R. Cure leg. um macho; Santa Catarina: Lages, 17.XII.1981, 2.XII.1981, S.S. Ortolan leg. dois machos; Blumenau, 1.X.65, V. Graf leg. uma fềmea. Depositados na Coleção Pe. J.S. Moure (DZUP). Parátipo do Rio Grande do Sul: Osório, 15.II.1992, I.A. dos Santos leg. uma fêmea; depositada no Laboratório de Pesquisas Biológicas (PUCRS).

Distribuição geográfica. Brasil: São Paulo, Paraná, Santa Catarina, Rio Grande do Sul.

Etimologia. Espécie dedicada ao Prof. Sebastião Laroca (DZUP).

\section{Melissoptila marinonii sp.n.}

\section{Figs 3,61}

Fêmeas com cerdas lisas nas tíbias e basitarsos posteriores, nas áreas ventral e vêntro-lateral dos mesepisternos. Macho com pêlos plumosos nos mesepisternos.

Holótipo fêmea. Tegumento preto, tégulas castanhas; pernas castanho-enegrecidas, as posteriores com o ápice das tíbias e os basitarsos castanho-amarelados, os mediotarsos e distitarsos de um castanho claro. Tergos com larga margem amarela clara, nos esternos a margem estreita.

Pilosidade branca na cabeça com pêlos enegrecidos no vértice. Mesoscuto enegrecido orlado com branco, escutelo enegrecido; metanoto, propódeo e mesepisternos brancos; branca nos artículos basais das pernas, nas anteriores e medianas castanha nas tíbias, com cerdas enegrecidas no lado externo dos basitarsos, mais claras nos medianos, amarela nas tíbias e basitarsos posteriores, castanha clara junto à placa basitibial e no ápice dos basitarsos; cerdas ventrais dos basitarsos castanhofulvas. Tergo basal com faixas laterais amarelas; segundo ao quarto tergo amarelos, quinto e sexto levemente acastanhados; esternos amarelos com franja branca apical curta, aumentando o comprimento dos pêlos do segundo para o quinto.

Comprimento aproximado 10,0; largura da cabeça 3,56; comprimento do olho 1,82; distância interorbital superior 2,04 e a inferior 1,84.

Alótipo. Tegumento preto predominando, amarelo no labro e clípeo, neste com duas pequenas nódoas enegrecidas próximas das fóveas tentoriais; longa nódoa basal amarela nas mandíbulas. Tégulas enegrecidas. Pernas enegrecidas, basitarsos castanhos, demais tarsômeros castanho-amarelados. Tergos com larga orla esbranquiçada, muito estreita no basal.

Pilosidade branca na cabeça, com pêlos castanhos esparsos atrás do ocelo mediano. Branca na face ventral dos mesepisternos e amarelada na face lateral; mesoscuto com pêlos levemente amarelados em volta, e castanhos no disco; escutelo castanho; pernas predominantemente esbranquiçadas, lado ventral dos basitarsos fulvo-acastanhado. Amarela nos tergos, os pêlos amarelos também na base do primeiro tergo; amarela nos esternos, as franjas apicais brancas.

Comprimento aproximado 7,17; largura da cabeça 3,08; comprimento do olho 1,60; distância interorbital superior 1,84 e a inferior 1,52; comprimento dos três flagelômeros basais 0,$34 ; 0,48 ; 0,44$; diâmetro do segundo flagelômero 0,20. 
Holótipo fêmea. BRASIL, Minas Gerais: Araxá, 15.V.1965, C.T. Elias leg. Alótipo da mesma localidade, 20.V.65, C.\& C.T. Elias leg. Parátipos, Minas Gerais: Santa Juliana 4.VI.65, C. Elias leg. uma fềmea; São Gotardo, 11.VI.65, C. Elias leg. uma fêmea; Bambuí, VI.1953, C.A.C. Seabra leg. uma fêmea; Tapira, 27.V.65, C. Elias leg. quatro fềmeas; Perdizes, 6.IV.65, C. Elias leg. uma fêmea; Ibiá, 18.VI.65, C. Elias leg. uma fêmea; Araxá, 15.IV.65, C. Elias leg. uma fêmea; 22.IV.65 uma fêmea; 5.V.65 duas fềmeas; Paraná: Morretes (Rio do Meio), 7.III.65, Mitchell \& Moure leg. um macho. Depositados na Coleção Pe. J.S. Moure (DZUP).

Distribuição geográfica. Brasil: Minas Gerais, Paraná.

Etimologia. Em homenagem ao Prof. Renato Contin Marinoni (DZUP).

\section{Melissoptila mielkei sp.n.}

Figs $10,33,53,61$

Macho com pêlos espatulado-longos na área ventral dos mesepisternos; trocanteres medianos com pilosidade curta e densa, fềmures medianos com pilosidade curtíssima.

Holótipo macho. Tegumento preto; labro e clípeo amarelos, clípeo com duas nódoas pretas junto às fóveas tentoriais; mandíbulas com a metade basal amarela. Tégulas, ápice dos fêmures, tíbias e tarsos castanho-amarelados. Margem translúcida esbranquiçada larga nos tergos, castanha e estreita nos esternos.

Pilosidade branca na cabeça, mesepisternos e pernas, amarelo-palha no mesoscuto e escutelo, cerdas ventrais dos basitarsos amarelas. Branca nos tergos e esternos.

Comprimento aproximado 8,83; largura da cabeça 3,26; comprimento do olho 1,76; distância interorbital superior 2,16 e a inferior 1,68; comprimento dos três flagelômeros basais 0,$30 ; 0,44 ; 0,38$; diâmetro do segundo flagelômero 0,18 .

Variações. A pilosidade dos parátipos com o amarelo mais intenso no vértice e mesonoto.

Holótipo macho. BrasiL, Minas Gerais: Passos, VIII.1961, C. Elias leg. dois parátipos, machos, um com a mesma etiqueta e outro coletado na mesma localidade em 30.III.63. Depositados na Coleção Pe. J.S. Moure (DZUP).

Distribuição geográfica. Brasil: Minas Gerais.

Etimologia. Nome em homenagem ao Prof. Olaf H.H. Mielke (DZUP).

\section{Melissoptila mirnae sp.n.}

Fig. 61

Fêmea com margem estreita, do primeiro tergo, desprovida de pontos. Pilosidade do mesoscuto castanha.

Holótipo fêmea. Tegumento preto com mancha amarela na base das mandíbulas. Tégulas e pernas castanho-amareladas, basitarsos um pouco mais escuros. Primeiro tergo com margem translúcida castanha, do segundo ao quarto com larga margem amarelo-clara; esternos castanhos. 
Pilosidade branca na cabeça com poucos pêlos castanho-claros no vértice, entre os ocelos. Mesoscuto quase todo castanho, branco na base e nos lados; escutelo com pêlos castanhos e cremosos, restante do mesosoma branco; pernas esbranquiçadas, lado externo das tíbias medianas e cerdas ventrais dos basitarsos de um amarelo-fulvo-claro. Amarelo-esbranquiçada nos tergos e esternos, franja apical branca curta no terceiro e quarto e longa e irregular no quinto esterno.

Comprimento aproximado 6,60; largura da cabeça 2,84; comprimento do olho 1,68; distância interorbital superior 1,72 e a inferior 1,42.

Holótipo fềmea. Argentina, Buenos Aires: Moreno, 7.XII.1970, Fritz leg. Depositado na Coleção Pe. J.S. Moure (DZUP).

Distribuição geográfica. Argentina: Buenos Aires.

Etimologia. Espécie dedicada à Profa. Mirna Martins Casagrande (DZUP).

\section{Melissoptila montanicola sp.n.}

Figs $32,52,61$

Macho com pêlos plumosos na face ventral dos mesepisternos; clípeo micro-reticulado, com as nódoas enegrecidas laterais fundidas ao tegumento preto adjacente. Mesepisternos com densa micro-reticulação entre os pontos.

Holótipo macho. Tegumento preto com as seguintes áreas claras: labro e clípeo amarelos, o clípeo com duas nódoas enegrecidas junto às fóveas tentoriais, contínuas com o tegumento preto adjacente; mandíbulas com pequena nódoa amarela basal. Tégulas castanho-escuras; tarsômeros castanho-amarelados, os distitarsos amarelos. Tergo basal com margem translúcida estreita esbranquiçada.

Pilosidade amarelo-esbranquiçada na cabeça. Mesoscuto com pêlos amarelo-esbranquiçados, de um castanho claro na metade posterior do disco; castanhos, muito claros, na base e disco do escutelo; restante do escutelo, metanoto, propódeo, mesepisternos e pernas amarelo-esbranquiçados, estas com as cerdas ventrais dos basitarsos amarelas. Amarelo-cremosa na base do primeiro tergo, preta na faixa subapical, amarela nos flancos até a margem, deixando área glabra no meio; do segundo ao sexto tergo com larga faixa preta basal e a margem largamente amarelada, no segundo com estreita faixa basal pálida encoberta pela margem do primeiro; o distal enegrecido; nos esternos amarelo-esbranquiçada.

Comprimento aproximado 9,66; largura da cabeça 3,0; comprimento do olho 1,64; distância interorbital superior 1,96 e a inferior 1,40 ; comprimento dos três flagelômeros basais 0,$30 ; 0,52 ; 0,44$; diâmetro do segundo flagelômero 0,20.

Holótipo macho. EquAdor, Azuay: Santa Isabel, $65 \mathrm{~km} \mathrm{SW}$ Cuenca, 1013.III.1965, L.E. Peña leg., Depositado na Coleção Pe. J.S. Moure (DZUP).

Distribuição geográfica. Equador: Azuay.

Etimologia. nome alusivo à área geográfica.

\section{Melissoptila moureana sp.n.}

Figs $9,34,54,61$

Macho com a pilosidade dos fềmures medianos curta, decumbente e mais densa na base, segundo flagelômero pouco maior que o primeiro. Fêmea com 
margem lisa estreita no primeiro tergo; do segundo ao quarto esterno com franja apical branca, curta e uniforme; pontuação da metade distal do mesoscuto esparsa, os intervalos de dois a quatro diâmetros de ponto; sem área brilhante nas paroculares superiores.

Holótipo macho. Tegumento preto com o labro, clípeo e metade basal das mandíbulas amarelos; clípeo com duas nódoas enegrecidas junto às fóveas tentoriais, unidas ao tegumento negro das paroculares. Tégulas, ápice dos fêmures, tíbias e tarsos castanho-amarelados. Margem translúcida larga amarelo-pálida nos esternos e castanha no primeiro tergo.

Pilosidade branca nas genas, levemente amarelada no restante da cabeça, amarela no vértice. Amarelo-fulva nos lobos pronotais, mesoscuto e escutelo, amarelada no propódeo; branca na face ventral dos mesepisternos, amarela na face lateral; branca nos artículos basais ds pernas, amarela nos demais artículos e nas cerdas ventrais dos basitarsos. Amarela nos tergos e nos esternos.

Comprimento aproximado 7,83; largura da cabeça 3,22; comprimento do olho 1,80; distância interorbital superior 2,02 e a inferior 1,48; comprimento dos três flagelômeros basais 0,$28 ; 0,36 ; 0,32$; diâmetro do segundo flagelômero 0,20 .

Alótipo. Tegumento preto com mancha amarela no terço basal das mandíbulas. Tégulas castanho-amareladas, pernas com os artículos basais castanho-escuros, tíbias e tarsos com áreas castanho-amareladas e castanhas. Tergos com margem translúcida amarela, nos esternos esbranquiçada e estreita.

Pilosidade levemente amarelada na cabeça, branca nas genas e mais amarela no vértice. Amarelo-fulva nos lobos pronotais, mesoscuto e escutelo; branca no propódeo e lado ventral dos mesepisternos, estes amarelos na parte lateral; artículos basais das pernas com pêlos brancos, os demais amarelos e as cerdas ventrais dos basitarsos amarelo-fulvas. Amarela nos tergos e nos esternos; longa e semi-ereta na base e junto ao ápice do segundo ao quarto esterno, com franja apical branca curta do segundo ao quarto esterno.

Comprimento aproximado 7,50; largura da cabeça 2,84; comprimento do olho 1,68; distância interorbital superior 1,84 e a inferior 1,56.

Holótipo macho. Brasil, Mato Grosso: Cuiabá, 22.II.65, S. Laroca leg. Alótipo e 22 parátipos, 13 machos e 9 fêmeas, de Mato Grosso: Nossa Senhora Livramento, 1-5.II.1965, S.Laroca leg. Depositados na Coleção Pe. J.S. Moure (DZUP).

Distribuição geográfica. Brasil: Mato Grosso.

Etimologia. Dedicada ao Prof. Pe. Jesus Santiago Moure (DZUP).

\section{Melissoptila ornata sp.n.}

Fig. 61

Melissoptila (Ptilomelissa) pubescens; Urban, 1968: 71 (partim).

Fêmea com as áreas paroculares superiores brilhantes quase até os ocelos; base do propódeo com larga faixa grosso-pontuada.

Holótipo fêmea. Tegumento preto, tégulas e tarsômeros distais castanhos, margem translúcida castanha larga no primeiro tergo.

Pilosidade branca na cabeça com poucos pêlos enegrecidos atrás dos ocelos. 
Enegrecida no mesoscuto e escutelo, branca no propódeo, mesepisternos e artículos basais das pernas; de uma tonalidade clara de castanho nas tíbias e tarsos; cerdas ventrais dos basitarsos castanhas, levemente amareladas. Amarela do segundo ao quarto tergo, deixando uma estreita faixa castanha junto à base do segundo tergo, no quinto tergo castanha clara com pêlos brancos nos lados, no sexto tergo castanha; primeiro ao quarto esterno branca, inclusive na franja apical, com cerdas amareloacastanhadas de permeio, mais longas no meio do esterno; quinto e sexto esternos amarelo-castanhados, o quinto com franja branca apical longa.

Comprimento aproximado 7,0; largura da cabeça 3,08; comprimento do olho 1,80; distância interorbital superior 1,76 e a inferior 1,64.

Holótipo fêmea. Peru, Loreto: Pucallpa, 22.VII.1959, J.M. Schunke leg. Depositado na Coleção Pe. J.S. Moure (DZUP).

Distribuição geográfica. Peru: Loreto.

Etimologia. nome alusivo à faixa castanha do segundo tergo.

\section{Melissoptila paranaensis sp.n.}

Figs $7,19,35,55,62$

Macho com modificações nas pernas, com alargamento nas tíbias e basitarsos medianos e nos fêmures posteriores; trocanteres posteriores com o bordo posterior carenado. Fêmea com cerdas finas na face ventral dos mesepisternos.

Holótipo macho. Tegumento preto; labro, clípeo e grande parte das mandíbulas amarelo-esbranquiçados, clípeo com duas pequenas nódoas negras próximas das fóveas tentoriais; mandíbulas com mancha subapical amarelo-fulva. Tégulas, parte distal dos fêmures, tíbias e tarsos castanho-amarelados. Tergos e esternos com orla translúcida amarela.

Pilosidade branca na cabeça, levemente tingida com amarelo nas paroculares inferiores e no vértice. Amarelo-fulva no mesoscuto e escutelo, mais clara no propódeo; branca na área ventral dos mesepisternos e amarela nas proximidades dos lobos pronotais; branca nas pernas, levemente amarela nas tíbias e tarsos, amarela em certa luz nos tufos apicais dos trocanteres medianos. Amarelo-fulva no primeiro tergo, branca nos flancos, com faixa apical amarela um pouco mais larga no meio; do segundo ao quarto tergo preta na base, com faixa apical amarela mais larga no meio, em ângulo no terceiro e quarto tergos e com mistura de amarelo na base do segundo tergo; quinto e sexto tergos pretos na base, o quinto com faixa apical branca e o sexto tergo com franja castanha; no sétimo tergo preta; amarelo-esbranquiçada e longa nos esternos.

Comprimento aproximado 10,17; largura da cabeça 3,60; comprimento do olho 2,18; distância interorbital superior 2,48 e a inferior 1,96; comprimento dos três flagelômeros basais 0,$26 ; 0,54 ; 0,44$; diâmetro do segundo flagelômero 0,20 .

Alótipo. Tegumento preto predominando. Tégulas, mediotarsos e distitarsos castanho-amarelados. Somente o primeiro tergo com margem translúcida castanha.

Pilosidade branca na cabeça, amarelo-fulva no vértice. Mesoscuto, escutelo e metanoto amarelo-fulvos, de um tom mais claro no propódeo e metade dorsal dos 


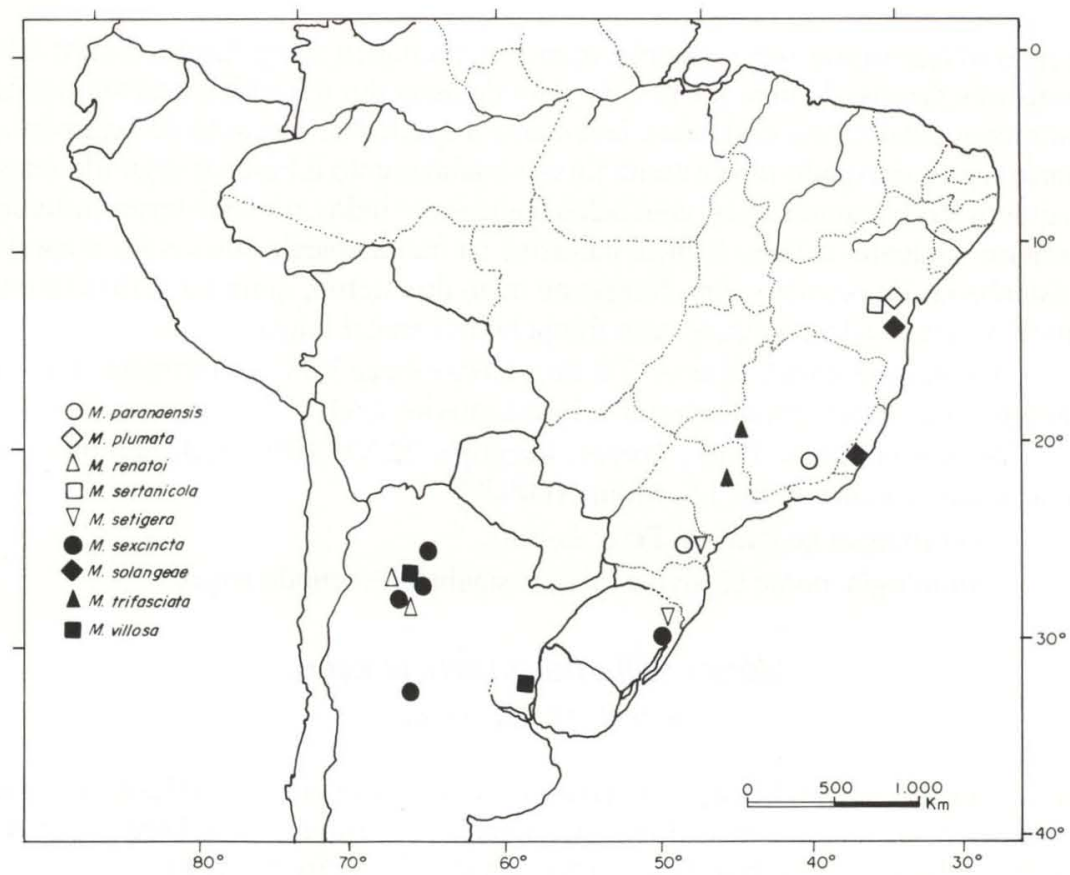

Figura 62. Mapa com a distribuição geográfica das espécies de Melissoptila.

mesepisternos, com cerdas finas castanho-claras na face ventral dos mesepisternos; branca nos artículos basais das pernas, nos demais amarela; tíbias medianas acastanhadas no lado externo; cerdas ventrais dos basitarsos posteriores castanhas. Amarelo-esbranquiçada na base do primeiro tergo, com faixas látero-apicais brancas, no disco pêlos finos esparsos castanhos; do segundo ao quarto tergo preta na base e no disco, com larga faixa apical branca densa; no segundo um pouco mais estreita no meio, no terceiro reta e no quarto tergo com pequena angulosidade mediana; quinto e sexto tergos pretos; esternos com cerdas castanho-escuras e franja apical branca curta do segundo ao quarto esterno.

Comprimento aproximado 10,33; largura da cabeça 3,08; comprimento do olho 2,0; distância interorbital superior 2,40 e a inferior 2,06.

Holótipo macho. Brasil, Paraná: Ponta Grossa (Vila Velha), 29-XI-65, T.B. Mitchell leg. Alótipo e um parátipo fêmea da mesma localidade, 30.XI.65, Moure \& Marinoni leg. Um parátipo, macho, com a mesma etiqueta do holótipo; da mesma localidade, 19.XI.65, 4.XII.65, T.B. Mitchell leg. duas fêmeas; Minas Gerais: Ouro Preto (1500m), 11.II.92, G.M. Faria leg. um macho. Depositados na Coleção Pe. J.S. Moure (DZUP).

Distribuição geográfica. Brasil: Minas Gerais e Paraná.

Comentário. Os machos aproximam-se de $M$. tandilensis pelas modificações das pernas. Nestas duas espécies, os fêmures e tíbias medianos têm a face ventral 
glabra, os fêmures posteriores são côncavos e largos, mais largos em $M$. tandilensis, os trocanteres posteriores têm pêlos curtos junto à carena angulosa. Entretanto as tíbias posteriores de $M$. tandilensis têm carena laminada e as de $M$. paranaensis têm carena fraca; os basitarsos medianos de $M$. tandilensis são muito largos. Outra espécie próxima, M. paraguayensis (Brèthes, 1909) tem tufo piloso basal nas tíbias medianas e longas cerdas subapicais junto à carena nos trocanteres posteriores.

Etimologia. Refere-se ao estado do Paraná, onde foram coletados quase todos os exemplares estudados.

\section{Melissoptila plumata sp.n. Figs 6,62}

Fêmea com cerdas densamente ramificadas nas tíbias e basitarsos posteriores; base do propódeo com faixa grosso-pontuada estreita.

Holótipo fêmea. Tegumento preto com pequena nódoa basal amarela nas mandíbulas. Tégulas enegrecidas; todos os basitarsos e as tíbias posteriores amarelo-acastanhados, lado ventral das tíbias anteriores e medianas castanho claro. Tergos com margem translúcida amarela, estreita no primeiro e larga nos seguintes; segundo e terceiro esternos com faixa apical castanha larga.

Pilosidade branca na cabeça com pêlos castanhos no vértice. Mesoscuto, escutelo e metanoto castanhos, restante do mesosoma branco; branca nas pernas com pêlos castanhos escuros no lado externo das tíbias medianas; tíbias e basitarsos posteriores amarelo-esbranquiçados com pêlos castanhos muito pálidos junto à placa basitibial; cerdas ventrais dos basitarsos amarelo-fulvas. Amarelo-esbranquiçada nos tergos e nos esternos.

Comprimento aproximado 10,17; largura da cabeça 3,28; comprimento do olho 1,76; distância interorbital superior 2,12 e a inferior 1,76.

Holótipo fêmea. Brasil, Bahia: Maracás, I.63, F.M. Oliveira leg. Depositado na Coleção Pe. J.S. Moure (DZUP).

Distribuição geográfica. Brasil: Bahia.

Etimologia. Nome alusivo às cerdas das tíbias e basitarsos posteriores da fêmea.

\section{Melissoptila renatoi sp.n.}

Figs $36,58,62$

Macho com clípeo amarelo, largamente orlado com preto junto à sutura epistomal; pilosidade plumosa na face ventral dos mesepisternos; base do propódeo com larga faixa grosso-pontuada.

Holótipo macho. Tegumento preto, labro amarelo, clipeo em grande parte amarelo, com larga área preta junto à sutura epistomal; metade basal das mandíbulas amarela. Tégulas castanhas, pernas castanho-amareladas nos mediotarsos e distitarsos. Tergos e esternos com margem estreita translúcida branco-amarelada.

Pilosidade branca, cerdas ventrais dos basitarsos amarelo-esbranquiçadas. 
Comprimento aproximado 8,67; largura da cabeça 3,04; comprimento do olho 1,56; distância interorbital superior 2,04 e a inferior 1,52; comprimento dos três flagelômeros basais 0,$32 ; 0,50 ; 0,44$; diâmetro do segundo flagelômero 0,22 .

Os dois exemplarares examinados bastante voados,com as asas desgastadas e ausência de pilosidade em grandes áreas.

Holótipo macho. ARGENTINA, Tucumán: Los Caudanes, 2.II.73, J.L. Neff leg. Um parátipo, macho; Catamarca: Andalgala, El Potrero, 19.III.73, J.L. Neff leg.. Depositados na Coleção Pe. J.S. Moure (DZUP).

Distribuição geográfica. Argentina: Tucumán, Catamarca.

Etimologia. Espécie dedicada ao amigo Renato Roxo Coutinho Dutra.

\section{Melissoptila sertanicola sp.n.}

Figs $37,56,62$

Macho com clípeo amarelo, orlado com preto junto à sutura epistomal; face ventral dos mesepisternos com pêlos lanceolados; base do propódeo com faixa grosso-pontuada larga; quarto e quinto esternos com franja apical completa, no segundo e terceiro só franjas laterais.

Holótipo macho. Tegumento preto com labro, metade basal das mandíbulas e grande parte do clípeo amarelos, o clípeo com área preta, de contorno irregular, junto à sutura epistomal. Tégulas castanhas, tíbias e tarsos castanho-amarelados. Primeiro ao terceiro tergo com margem translúcida amarelo-esbranquiçada, mais estreita no primeiro.

Pilosidade branca na cabeça; branca no mesosoma, e castanha, muito clara, no escutelo; branca nas pernas com cerdas amarelas pálidas no lado ventral dos basitarsos. Branca e esparsa no metasoma.

Comprimento aproximado 6,50; largura da cabeça 2,80; comprimento do olho 1,56; distância interorbital superior 1,72 e a inferior 1,38; comprimento dos três flagelômeros basais 0,$30 ; 0,64 ; 0,54$; diâmetro do segundo flagelômero 0,18 .

Holótipo macho. Brasil, Bahia: Maracás, IX.65, F.M. Oliveira leg. Depositado na Coleção Pe. J.S. Moure (DZUP).

Distribuição geográfica. Brasil: Bahia.

Etimologia. Nome alusivo à região em que foi coletado o holótipo.

\section{Melissoptila setigera sp.n.}

Figs $4,8,62$

Fêmea com cerdas lisas nas tíbias e basitarsos posteriores e cerdas nas faces ventral e vêntro-lateral dos mesepisternos. Macho com pêlos plumosos nos mesepisternos.

Holótipo fêmea. Tegumento preto. Nódoa castanho-amarelada subapical no lado externo das tíbias posteriores, tarsômeros castanhos, excetuando os basitarsos enegrecidos. Sem margem translúcida clara nos tergos.

Pilosidade branca nas genas, parte do clípeo, paroculares inferiores e junto às antenas, preta no restante da fronte, paroculares e vértice. Preta no mesoscuto, 
escutelo e metanoto; branco-amarelada no propódeo e nos mesepisternos, com pêlos enegrecidos na área dorsal dos mesepisternos; branco-amarelada nos artículos basais das pernas, enegrecida nas tíbias e tarsos anteriores e medianos; com cerdas amarelo-fulvas no lado ventral dos trocanteres e base dos fêmures medianos; tíbias e basitarsos posteriores com cerdas longas amarelas lisas; cerdas ventrais dos basitarsos castanho-enegrecidas nos anteriores a castanho-amareladas nos demais. Enegrecida na base do primeiro tergo, castanho-clara nos flancos e nos bordos, lateralmente com faixas amarelas denso-pilosas; do segundo ao quarto tergo preta na base com larga faixa amarela apical denso-pilosa, tergo distal preto e o quinto com fímbria castanha; nos esternos castanho-enegrecida, do segundo ao quarto com franja apical branca curta e irregular.

Comprimento aproximado 11,0; largura da cabeça 3,92; comprimento do olho 2,16; distância interorbital superior 2,44 e a inferior 2,20.

Alótipo. Tegumento preto, labro e clípeo amarelo-claros; mandíbulas com nódoa basal amarela. Ápice e lado ventral das tíbias posteriores e tarsômeros castanho-amarelados; esternos castanhos no disco, orla esbranquiçada.

Pilosidade branco-amarelada na cabeça, enegrecida no vértice; preta no dorso do mesosoma; amarelo-esbranquiçada no propódeo com pêlos fuscos láterobasais; amarelo-esbranquiçada nos mesepisternos e artículos basais das pernas; cerdas ventrais dos basitarsos amarelo-fulvas. Primeiro tergo com mescla de branco e castanho-acinzentado na base, no disco enegrecida e com faixas látero-apicais amarelas; do segundo ao quinto tergo com larga faixa apical amarela e a base preta, preta nos tergos distais; esternos com franja apical amarelo-esbranquiçadas e cerdas castanhas no restante.

Comprimento 9,5; largura da cabeça 3,67m; comprimento do olho 2,04; distância interorbital superior 2,20 e a inferior 1,80; três flagelômeros basais 0,40; 0,56; 0,50; diâmetro do segundo flagelômero 0,24.

Variações. Parátipo macho com faixa amarela completa no tergo basal; mesoscuto com pêlos brancos na base, e o tegumento do clípeo com duas nódoas negras próximas das fóveas tentoriais.

Holótipo fêmea. Brasil, Rio Grande do Sul: São Francisco de Paula, 27.II.1991, C. Schlindwein leg. Alótipo com a mesma etiqueta. Parátipos, Paraná: Piraquara, 26.IV.75, Laroca leg. duas fêmeas. Depositados na Coleção Pe. J.S. Moure (DZUP). Parátipos do Rio Grande do Sul: Cambará do Sul, 6.II.93, I.A. dos Santos leg. quatro machos; Osório, 14.III.92, I.A. dos Santos leg. um macho; depositados no Laboratório de Pesquisas Biológicas (PUCRS).

Distribuição geográfica. Brasil: Paraná, Rio Grande do Sul.

Etimologia. Nome alusivo às cerdas lisas das tíbias e basitarsos das pernas posteriores das fêmeas.

\section{Melissoptila sexcincta sp.n.}

Figs $38,57,62$

Macho com pêlos plumosos nos mesepisternos; trocanteres medianos com pêlos espatulado-curtos, densos, resultando um aspecto aveludado; carenas do sexto esterno paralelas aos bordos e próximas dos mesmos. 
Holótipo macho. Tegumento preto; labro e clípeo amarelos, o clípeo com duas nódoas pequenas pretas próximas às fóveas tentoriais; mandíbulas com mancha subapical e o terço basal amarelos. Tégulas castanho-amareladas, tíbias e tarsos amarelos com leve tonalidade castanha. Tergos e esternos com margem translúcida amarelo-esbranquiçada estreita.

Pilosidade branco-amarelada; cerdas ventrais dos basitarsos amarelas tingidas levemente de castanho. Tergo basal com faixas laterais branco-amareladas, do segundo ao sexto tergo enegrecida na base e com faixa apical branco-amarelada; branca nos esternos.

Comprimento aproximado 8,83; largura da cabeça 3,06; comprimento do olho 1,68; distância interorbital superior 1,92 e a inferior 1,60; comprimento dos três flagelômeros basais 0,$26 ; 0,54 ; 0,40$; diâmetro do segundo flagelômero 0,20.

Holótipo macho. ARGENTINA, Tucumán: M. Arnau leg., sem indicação de data. Parátipos. Quatro machos com os mesmos dados do holótipo; Catamarca: Água de las Palomas, 26.II.73, J.L. Neff leg. um macho; Tacanas, I.1947, sem indicação de coletor, um macho; Salta (Coronel Moldes), 4.II.948, Willink \& Monrós leg. um macho; Salta: (km 21 R 34), 14.I.1973, sem coletor, um macho; Córdoba: 19.XI.70, M.A. Fritz leg. um macho; El Alto, 28.XI.1953, sem indicação de coletor, um macho. Depositados na Coleção Pe. J.S. Moure (DZUP). Parátipo do Brasil, Rio Grande do Sul, Osório, 15.II.92, I.A. dos Santos leg. um macho; depositado no Laboratório de Pesquisas Biológicas (PUCRS).

Distribuição geográfica. Argentina: Salta, Tucumán, Catamarca, Córdoba; Brasil, Rio Grande do Sul.

Etimologia. Nome alusivo ao aspecto barrado dos tergos.

\section{Melissoptila solangeae sp.n.}

Fig. 62

Fêmea com cerdas castanhas formando uma estria nas tíbias posteriores, junto à placa basitibial; paroculares superiores com área larga brilhante, quase desprovida de pontos; base do propódeo com faixa grosso-pontuada larga; tegumento da fronte fosco com pontos grandes.

Holótipo fềmea. Tegumento preto; mancha amarela discal nas mandíbulas; tégulas enegrecidas; tarsos castanhos; margem castanha no tergo basal e amareloesbranquiçada nos esternos.

Pilosidade branca na cabeça, castanha no vértice. Enegrecida no mesoscuto e escutelo, mesoscuto com fina orla branca, restante do mesosoma e artículos basais das pernas brancos; amarelo-esbranquiçada nas tíbias anteriores, os basitarsos mais amarelos com pêlos castanhos de permeio; tíbias medianas e basitarsos medianos e posteriores amarelo-esbranquiçados; tíbias posteriores com as cerdas do lado externo amareladas, e cerdas castanhas junto à placa basitibial formando uma estria curta; cerdas ventrais dos basitarsos amarelo-fulvas. Amarela nos tergos e esternos; os esternos distais amarelo-fulvos, os demais esternos brancos na base e com franja apical também branca. 
Comprimento aproximado 8,30; largura da cabeça 3,60; comprimento do olho 1,94; distância interorbital superior 2,02 e a inferior 1,78.

Holótipo fêmea. BRASIL, Bahia: Maracás (970m), VI.1961, F.M. Oliveira leg. Dois parátipos, fêmeas, com a mesma etiqueta do holótipo e uma fêmea com os mesmos dados, coletada em IX.65; Bahia: Vitória da Conquista, 10-20.V.61, F.M. Oliveira leg. uma fêmea; Espírito Santo: Baixo Guandu, 17.V.70, C.\& C.T. Elias leg. seis fêmeas; 25.IV.70 três fềmeas. Depositados na Coleção Pe. J.S. Moure (DZUP).

Distribuição geográfica. Brasil: Bahia, Espírito Santo.

Etimologia. Espécie dedicada à Profa. Dilma Solange Napp (DZUP).

\section{Melissoptila trifasciata sp.n.}

Fig. 62

Fêmea com faixa amarela no clípeo, tergos com faixas pilosas claras apicais.

Holótipo fêmea. Tegumento preto, labro amarelado com castanho na base, clípeo com faixa amarela. Tégulas, mediotarsos e distitarsos amarelo-fulvos. Tergos com larga margem translúcida branco-amarelada.

Pilosidade branca na cabeça, amarelada no vértice. Mesoscuto e escutelo amarelo-fulvos, mesepisternos brancos passando a amarelos na face lateral, lobos pronotais amarelos, propódeo e artículos basais das pernas brancos, tíbias e basitarsos branco-amarelados; as tíbias posteriores com pêlos castanhos junto à placa basitibial, face ventral dos basitarsos amarelo-fulva. Tergo basal com faixas laterais amarelas; do segundo ao quarto tergo enegrecida na base com larga faixa apical amarela, mais esbranquiçada e em ângulo no meio do quarto tergo, nos demais estreitando somente nos flancos; castanha no quinto e sexto tergos, mais escura no sexto; amarelo-fulva nos esternos, com franjas apicais longas amareladas.

Comprimento aproximado 10,5; largura da cabeça 3,44; comprimento do olho 1,84; distância interorbital superior 2,16 e a inferior 1,84 .

Holótipo fêmea. Brasil, Minas Gerais: Passos, IV.62, C. Elias leg. Três parátipos, fêmeas, de São Paulo: Batatais, III.43, A. Stafuzza leg. Depositados na Coleção Pe. J.S. Moure (DZUP).

Distribuição geográfica. Brasil: Minas Gerais, São Paulo.

Etimologia. Nome alusivo ao aspecto barrado do metasoma.

\section{Melissoptila villosa sp.n.}

Figs $17,18,39,59,62$

Melissoptila (Ptilomelissa) pubescens; Urban, 1968: 71 (partim).

Macho com pêlos plumosos na face ventral dos mesepisternos; pêlos curtos e densos com aspecto aveludado nos trocanteres medianos; curtos na face ventral dos fêmures medianos. Fêmea com escutelo denso-pontuado.

Holótipo macho. Tegumento preto; labro e clípeo amarelos, o clípeo com nódoas pretas próximas das fóveas tentoriais; mandíbulas com mancha amarela 
basal ocupando mais de um terço do seu comprimento. Tégulas, ápice dos fêmures, tíbias e tarsos castanho-amarelados. Tergos com larga margem translúcida amarelo-esbranquiçada, mais estreita nos esternos.

Pilosidade branco-amarelada na cabeça, no mesoscuto, escutelo e adjacências dos mesepisternos; restante dos mesepisternos, propódeo e artículos basais das pernas com pêlos brancos; amarelo-esbranquiçada nas tíbias e tarsos, inclusive no lado ventral dos basitarsos e área denso-pilosa dos trocanteres medianos. Amarela nos tergos e esternos.

Comprimento aproximado 7,50; largura da cabeça 2,92; comprimento do olho 1,60; distância interorbital superior 1,80 e a inferior 1,48; comprimento dos três flagelômeros basais 0,$26 ; 0,38 ; 0,34$; diâmetro do segundo flagelômero 0,18 .

Alótipo. Tegumento preto; mandíbulas amarelas na base, com longa mancha discal amarela. Tégulas, mediotarsos e distitarsos castanho-amarelados. Tergo basal com larga margem amarelo-esbranquiçada translúcida, mais larga do segundo ao quarto tergo e visivel sob a pilosidade clara; esternos castanhos com larga margem translúcida amarelada.

Pilosidade branca na cabeça, castanha pálida no vértice. Castanha no mesoscuto e escutelo, branca na base do mesoscuto e no restante do mesosoma incluindo os artículos basais das pernas; amarelo-esbranquiçada nas tíbias e tarsos, nos basitarsos anteriores com mescla de castanho; amarelo nas cerdas ventrais dos basitarsos. Amarelo-esbranquiçada nos tergos e nos esternos, os esternos com franja apical branca.

Comprimento aproximado 8,$0 ;$ largura da cabeça 3,12; comprimento do olho 1,70; distância interorbital superior 2,0 e a inferior 1,72.

Holótipo macho. ARGENTINA, Entre Rios: $1^{\circ}$ de Mayo, II.55, Fritz leg. Alótipo, Tucumán: S. Pedro Colalao, I-II.49, P.J.M. Arnau leg. Um parátipo, macho, com a mesma etiqueta de procedência do holótipo. Demais parátipos - Tucumán: [sem data] M. Arnau leg. três machos; S. Pedro Colalao, I.47, II.49, Arnau leg. dois machos; Entre Rios: Pronunciamento, I.1961, J. Foerster leg. um macho; II.1962, F.H. Walz leg., três machos. Depositados na Coleção Pe. J.S. Moure (DZUP).

Distribuição geográfica. Argentina: Tucumán, Entre Rios.

Etimologia. Nome alusivo à pilosidade aveludada dos trocanteres medianos dos machos.

\section{NOTAS TAXONÔMICAS}

\section{Melissoptila argentina Brèthes, 1910 sp. rev.}

Melissoptila argentina Brèthes, 1910: 300.

Melissoptila (Ptilomelissa) argentina; Michener \& Moure, 1956: 286.

Melissoptila (Ptilomelissa) pubescens; Urban, 1968: 71 (partim).

Ao descrever a espécie, Brèthes teve em mãos exemplares de diversas Províncias da Argentina. O exame dos tipos, que estão depositados no Museu Argentino de Ciências Naturais Bernardino Rivadávia, Buenos Aires, permitiu reconhecer $M$. argentina e esclarecer a posição sistemática dos demais cótipos.

Revta bras. Zool. 15 (1): 1 - 46, 1998 
MiCHENER \& MOURE (1956) designaram como lectótipo uma fêmea coletada em Mendoza e comentaram que a série tipo era composta de duas ou três espécies. URBAN (1968) colocou-a na sinonímia de $M$. (P.) pubescens.

O lectótipo tem toda a pilosidade pálida; clípeo denso-pontuado sem microreticulação entre os pontos; supraclipeal com área brilhante desprovida de pontos grandes; paroculares superiores micro-reticuladas junto às órbitas, sem área lisa; mesepisternos com densa micro-reticulação entre os pontos; mesoscuto na metade posterior e o escutelo anteriormente com áreas lisas maiores que os pontos; propódeo com larga área grosso-pontuada; tergo basal com margem lisa mais larga que dois diâmetros de ocelo. Além do lectótipo, foram examinados exemplares da Argentina, Mendoza; Paraguai. Peribebuy; e do Brasil, Paraná, Ponta Grossa, Vila Velha.

Os cótipos são abelhas de espécies diferentes, a maioria delas descrita neste trabalho. As duas fêmeas de Jujuy foram identificadas como Melissoptila larocai que ocorre no sul e sudeste do Brasil; o macho da mesma localidade, foi identificado como Melissoptila villosa, reconhecido facilmente pelo aspecto aveludado da pilosidade dos trocanteres medianos, também ocorre em Tucumán e Entre Rios, Argentina; o macho de Salta, identificado como Melissoptila pubescens que ocorre no Brasil e Argentina; e a fêmea de Misiones, sem a cabeça, como Melissoptila carinata. Um macho de Jujuy, sem etiqueta de cótipo, porém com etiqueta de identificação original, sem dúvida, também pertencente à série típica, foi identificado como Melissoptila albinoi.

\section{Melissoptila ochromelaena (Moure, 1943) sp.rev.}

Ptilomelissa ochromelaena Moure, 1943: 483.

Melissoptila (Ptilomelissa) thoracica; Urban, 1968: 77 (partim).

O macho tipo de M. ochromelaena, depositado na Coleção de Entomologia Pe. J.S. Moure (DZUP), está com a pilosidade do mesoscuto bastante danificada, sem a área enegrecida que caracteriza a espécie e as antenas somente com o escapo, pedicelo e o flagelômero basal. Tendo estudado machos e fêmeas do Espírito Santo, Rio de Janeiro, São Paulo e Paraná, e comparado com o tipo, foi possível reconhecer esta espécie. Os machos têm pilosidade amarelo-palha no terço basal do mesoscuto e castanho-escura no restante do mesoscuto e no escutelo; larga faixa basal enegrecida do segundo ao quinto tergo, faixa estreita marginal esbranquiçada, mais estreita no meio do segundo e terceiro tergos; segundo flagelômero longo, cerca de três vezes o comprimento do primeiro; primeiro tergo com margem estreita desprovida de pontos; franja densa e reta na margem do terceiro ao quinto esterno. As fêmeas têm pilosidade enegrecida no dôrso do mesosoma; tergos pretos na base e com faixas látero-apicais brancas nos três basais, no quarto tergo com faixa apical completa; área posterior do disco do mesoscuto com pontos muito esparsos; escutelo com pontuação fina esparsa. 


\section{Melissoptila pacifica (Cockerell, 1914)}

Leptometria pacifica Cockerell, 1914, Jour. N.Y. Ent. Soc. 22: 319.

Melissoptila (Ptilomelissa) pacifica; Moure \& Michener, 1955, Dusenia Curitiba, 6 (6): 304.

O holótipo macho depositado no Snow Entomological Museum, Kansas, USA, tem pilosidade amarelo-dourada nos tergos e amarelo-pálida no terço basal do mesoscuto, no restante do mesoscuto faltam os pêlos; área ventral dos mesepisternos com pêlos plumosos e a base do propódeo estreitamente grosso-pontuada. Também foram examinados espécimens coletados em Loja, EQUADOR; os machos com pilosidade castanha na metade distal do mesoscuto, e as fêmeas com pêlos castanhos no dorso do mesosoma e área brilhante larga sem micro-reticulação nas paroculares superiores. Foram vistas fềmeas com variação nos pêlos do escutelo: castanho-claros no disco, castanho-claros somente nos flancos, ou amarelo-acastanhado-pálidos.

\section{NOTAS MORFOLÓGICAS}

O estudo comparativo do sétimo esterno dos machos revelou algumas peculiaridades: M. paranaensis tem a mesma forma que $M$. paraguayensis; em $M$. renatoi as placas laterais são projetadas para fora e os bordos anterior e posterior são paralelos; em M. larocai há redução das placas medianas; em M. catamarcensis, como em $M$. dama, as placas medianas são longas e projetadas para trás; em $M$. aurea e $M$. bahiana as placas medianas são arredondadas e quase igualam a largura das laterais; em $M$. cacerensis, $M$. carinata, $M$. grafi, $M$. renatoi e $M$. sertanicola, as placas medianas são alongadas.

Quanto à espata da genitália do macho podem ser feitas as seguintes comparações: os bordos anterior e posterior quase retos, sem alargamento mediano em M. mielkei e $M$. minarum; sem alargamento mediano porém com os bordos anterior e posterior sinuosos em M. bahiana, $M$. grafi, M. larocai, $M$. sertanicola e $M$. villosa; espata alargada, com os bordos um pouco convexos no meio em $M$. albinoi, $M$. aurea, $M$. carinata, $M$. clypeata, $M$. ecuatoriana, $M$. montanicola e $M$. moureana; larga nos flancos e com os bordos um pouco convexos no meio em $M$. cacerensis, $M$. catamarcensis, $M$. chilena, $M$. paranaensis e $M$. renatoi.

Devido à semelhança de padronagem, URBAN (1968) incluiu o exemplar de $M$. boliviana na listagem de $M$. thoracica; exemplar de $M$. ornata na listagem de M. pubescens.

\section{Chave para as espécies sulamericanas}

\section{FÊMEAS}

1. Clípeo com faixa subapical amarela. Mesoscuto com pilosidade amarelo-fulva .

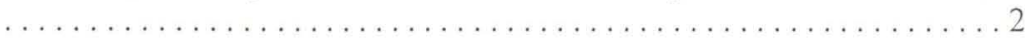

- Clípeo inteiramente preto; quando com pequena área subapical amarela com pêlos enegrecidos no mesoscuto ......................... 
2. Segundo ao quarto tergo com pilosidade uniforme amarelo-esbranquiçada. Paroculares superiores brilhantes com área micro-reticulada larga e sem pontos junto ao vértice. Brasil: Paraíba, Bahia, Rio de Janeiro, Mato Grosso . .... . aliceae sp.n.

- Segundo ao quarto tergo com pilosidade enegrecida na base e larga faixa amarela apical, mais esbranquiçada e em ângulo no meio do quarto tergo. Paroculares superiores foscas, com micro-reticulação fraca e pontos até junto aos ocelos laterais. Brasil: Minas Gerais, São Paulo ............. trifasciata sp.n.

3. Face ventral dos mesepisternos com cerdas finas e lisas, eretas ou arqueadas na

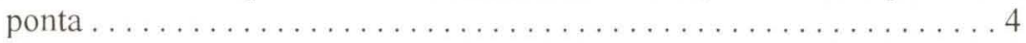

- Face ventral dos mesepisternos com pêlos plumosos, porém mais curtos do que no restante dos mesepisternos

4. Escopa tibial com cerdas lisas nas faces dorsal e posterior, raramente com cerdas ramificadas de permeio. Face vêntro-lateral dos mesepisternos com cerdas

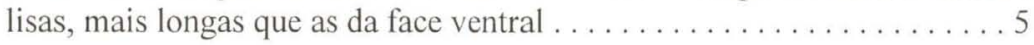

- Escopa tibial com as cerdas ramificadas predominando. Face vêntro-lateral dos mesepisternos com pêlos plumosos . ................. 8

5. Segundo ao quarto tergo com pêlos enegrecidos basais e faixa apical amarela ou castanho-bronzeada. Terceiro e quarto esternos com pêlos enegrecidos . . .6

- Segundo ao quarto tergo com pilosidade amarelo-fulva. Terceiro e quarto esternos com pêlos amarelos ou amarelo-fulvos . . . . . . . . . . . . . 7

6. Basitarsos posteriores com cerdas castanho-enegrecidas na face posterior. Pilosidade da metade dorsal dos mesepisternos branca a levemente amarelada. Segundo ao quarto tergo com faixa apical pilosa castanho-bronzeada. Brasil: Bahia, Minas Gerais, Espírito Santo . . . . . . . . . . . bahiana sp.n.

- Basitarsos posteriores com cerdas amarelas. Pilosidade da metade dorsal dos mesepisternos com mescla de amarelo pálido e enegrecido. Segundo ao quarto tergo com faixa pilosa apical amarela. Brasil: Rio Grande do Sul ... setigera sp.n.

7. Escopas tibial e basitarsal com cerdas amarelas, sobre tegumento castanho-amarelado. Tergos com larga margem translúcida branco-amarelada. Brasil: Minas Gerais, Paraná . . . . . . . . . . . . . . . . . marinonii sp.n.

- Escopas tibial e basitarsal com cerdas negras sobre tegumento também negro. Tergos pretos, sem orla clara. Brasil: São Paulo . . . . . . . . buzzii sp.n.

8. Pilosidade do mesoscuto e escutelo amarelo-fulva. Tergos com pilosidade preta na base e faixa apical branca. Escopa basitarsal com cerdas ramificadas porém os ramos finos e longos, não eretos. Brasil: Minas Gerais, Paraná . . . paranaensis sp.n.

- Pilosidade do mesoscuto e do escutelo castanha com áreas brancas. Tergos com pilosidade de colorido uniforme amarelado. Escopa basitarsal com cerdas lisas ou ramificadas porém estas com os ramos eretos ............9 
9. Primeiro tergo com margem larga desprovida de pontos grandes. Segundo tergo com margem lisa larga nos lados e mais estreita no meio. Face dorsal das tíbias medianas com pilosidade castanha. Escopa basitarsal com cerdas lisas, somente algumas ramificadas de permeio. Paraguai: S.Bernardino; Argentina: Córdoba, Formosa, Mendoza; Brasil: Minas Gerais, São Paulo, Paraná, Santa Catarina, Rio Grande do Sul ........ paraguayensis (Brèthes, 1909)

- Primeiro tergo com margem desprovida de pontos larga nos flancos e mais estreita no meio. Segundo tergo com margem lisa estreita a muito estreita, não alargando para os lados. Face dorsal das tíbias medianas com pilosidade amarela a amarelo-fulva. Escopa basitarsal com cerdas ramificadas . . . 10

10. Esternos com cerdas semi-eretas. Metade basal dos fêmures anteriores com pêlos longos, fina e densamente ramificados. Argentina: Buenos Aires; Brasil, Rio Grande do Sul .......................... carinata sp.n.

- Esternos com cerdas finas levemente arqueadas para trás. Metade basal dos fêmures anteriores com cerdas longas finas. Argentina: Córdoba, Santiago del Estero ................................. hirsutula sp.n.

11. Mesoscuto com pilosidade branca, amarelada ou amarelo-fulva . . . . . . 12 - Mesoscuto com pêlos castanhos ou enegrecidos, ao menos em parte . . . . . . 22 22

12. Segundo tergo com pilosidade esparsa na área médio-apical . . . . . . . . . 13

- Pilosidade do segundo tergo densa até o bordo ................ 15

13. Depressão marginal larga do segundo ao quarto tergo, em ângulo para a base e com pontuação esparsa ........................... 14

- Segundo ao quarto tergo sem depressão marginal, pontuação densa até a margem. Tergos com ou sem faixa apical branco-pilosa. Argentina: Misiones; Brasil: Mato Grosso do Sul, Minas Gerais, Espírito Santo, Rio de Janeiro, São Paulo, Paraná, Santa Catarina .................. thoracica (Smith, 1854)

14. Segundo ao quarto tergo com pêlos pretos na base e larga faixa apical branca, geralmente interrompida no meio do segundo. Tíbias posteriores com cerdas esbranquiçadas. Basitarsos posteriores com cerdas ferrugíneas ventralmente. Argentina: Jujuy, Salta Tucumán, Santa Fé, Buenos Aires, Mendoza. Chile: Bio-Bio. Brasil: Paraná, Rio Grande do Sul . . . tandilensis Holmberg, 1884 - Tergos com pilosidade preta. Tíbias posteriores com cerdas castanhas na face posterior, ao longo do comprimento. Basitarsos posteriores com cerdas ventrais enegrecidas. Bolivia: Oruro . ............. boliviana sp.n.

15. Tergos com pilosidade de colorido uniforme ................ 16

- Tergos com pilosidade enegrecida na base e faixa apical amarela ou cremosa, geralmente do segundo ao quarto. Argentina: Misiones; Brasil: Minas Gerais, Espírito Santo, Rio de Janeiro, São Paulo, Paraná, Santa Catarina, Rio Grande do Sul ............... minarum (Bertoni \& Schrottky, 1910)

16. Cerdas lisas curtas na face anterior dos trocanteres anteriores e na metade basal dos respectivos fêmures. Face posterior dos fềmures anteriores com pêlos longos finos densamente ramificados, em contraste com a área cerdosa . . 17

- Cerdas curtas ou pêlos plumosos na face anterior dos trocanteres anteriores, fêmures anteriores com pêlos plumosos . ................ 18 
17. Primeiro tergo com larga margem desprovida de pontos grandes. Escopas tibiais e basitarsais com cerdas amarelo-fulvas. Basitarsos anteriores com pilosidade castanha. Brasil: Paraná, Rio Grande do Sul . . . . . claudii Urban, 1988

- Primeiro tergo com margem estreita desprovida de pontos grandes. Escopas tibiais e basitarsais esbranquiçadas. Basitarsos anteriores com pilosidade amareloesbranquiçada. Argentina: Tucumán, Jujuy, Buenos Aires, Mendoza. ..... . dama (Vachal, 1904)

18. Primeiro tergo com margem glabra muito estreita, mais estreita que um diâmetro de ocelo. Margem do segundo ao quarto tergo translúcida, branco-amarelada. Base do propódeo com faixa grosso-pontuada estreita. Brasil: Mato Grosso . . . . ........................ moureana sp.n.

- Primeiro tergo com margem glabra larga, no meio mais larga que um diâmetro de ocelo, e mais larga nos lados. Margem translúcida dos tergos variavel. Base

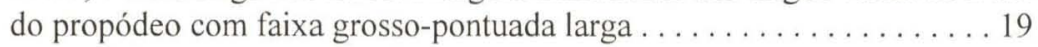

19. Paroculares superiores com larga área micro-reticulada, desprovida de pontuação grossa e de área brilhante junto às órbitas. Supraclipeal com área discal brilhante sem pontos. Mesoscuto com pontuação mais esparsa na metade posterior. Argentina, Mendoza; Brasil: Paraná .... argentina Brèthes, 1910

- Paroculares superiores brilhantes, sem área micro-reticulada desprovida de pontos grandes junto aos olhos. Supraclipeal variável. Mesoscuto variavel . . . . 20

20. Mesoscuto denso-pontuado até o ápice. Supraclipeal com pontos grandes no disco, sem área lisa brilhante. Brasil, Amazonas, Goiás, Mato Grosso. Argentina, Salta, Jujuy . . . . . . . . . . . . . pubescens (Smith, 1879)

- Mesoscuto com os intervalos maiores que os pontos na metade posterior do disco. Supraclipeal com área lisa brilhante no disco . . . . . . . . . . 21

21. Clípeo com micro-reticulação entre os pontos. Tergo basal com larga margem lisa. Paraguai: Puerto Bertoni; Argentina: Misiones; Brasil: Minas Gerais, Espírito Santo, São Paulo e Paraná . . vulpecula Bertoni \& Schrottky, 1910

- Clípeo sem micro-reticulação entre os pontos. Tergo basal com a margem lisa estreita, mais ainda no meio (um diâmetro de ocelo). Chile, Coquimbo, Santiago ............................. chilena sp.n.

22. Paroculares superiores foscas, separadas do vértice por elevação do tegumento entre os olhos e os ocelos laterais . ......................23

- Paroculares superiores brilhantes ou com micro-reticulação, contínuas com o vértice ou separadas por curta área elevada, porém não como acima . . . 24

23. Cerdas das escopas tibiais com ramos eretos, cerca de cinco a cada lado. Metade distal do disco do mesoscuto com os espaços entre os pontos igualando dois a quatro diâmetros de ponto. Paraguai: Puerto Bertoni. Argentina: Misiones; Brasil: Ceará, Bahia, Minas Gerais, São Paulo, Paraná . . . . . . . . . . . . richardiae Bertoni \& Schrottky, 1910 - Cerdas das escopas tibiais com os ramos finos e longos, dobrados em gancho na ponta, cerca de 10 a cada lado. Metade distal do disco do mesoscuto quase glabra, os pontos esparsos. Brasil: São Paulo, Paraná . . similis Urban, 1988 
24. Cerdas das escopas tibiais e basitarsais densamente ramificadas, os ramos finos e curtos, cerca de 15 a cada lado. Brasil: Bahia .......... plumata sp.n.

- Cerdas das escopas tibiais e basitarsais com os ramos eretos, cerca de 5 ramos a cada lado . . . . . . . . . . . . . . . . . . . . . . . . 25

25. Pelo menos o segundo tergo com pêlos escuros no disco e faixa apical clara, geralmente do segundo ao quarto tergo com faixa pilosa apical clara e pêlos escuros para a base ............................ 26

- Pilosidade do segundo ao quarto tergo de colorido uniforme . .......... 33

26. Somente o segundo tergo com faixa basal de pêlos castanhos e larga faixa apical amarela completa. Terceiro e quarto tergos amarelos. Paroculares superiores com área brilhante e sem pontos quase até os ocelos. Peru: Loreto .

ornata sp.n.

- Segundo ao quarto tergo com faixa basal enegrecida e margem com pêlos claros formando faixa completa ou interrompida no meio, ou com número menor de tergos com faixa, porém não somente o segundo. Paroculares superiores

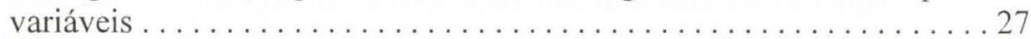

27. Pilosidade do mesoscuto inteiramente preta ou castanha .......... 28

- Pilosidade do mesoscuto não inteiramente enegrecida, com área basal ou também

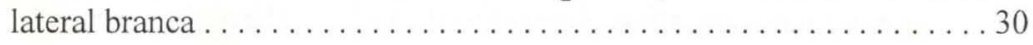

28. Segundo tergo com larga área médio-apical desprovida de pontos grandes, glabra, interrompendo a faixa branco-pilosa apical. Pilosidade enegrecida na metade dorsal dos mesepisternos. Brasil: Rio de Janeiro, São Paulo, Paraná, Santa Catarina ...................... aureocincta Urban, 1968

- Segundo tergo pontuado até a margem, com pilosidade até o ápice. Mesepisternos com pilosidade variavel, branca ou enegrecida na metade dorsal . . . . 2 29

29. Metade dorsal dos mesepisternos com pêlos brancos ou branco-amarelados. Faixa branco-pilosa apical do segundo e terceiro tergos mais estreita no meio. Terceiro e quarto esternos com franja branca de comprimento uniforme. Brasil: Espírito Santo, Rio de Janeiro, São Paulo, Paraná . ............ ochromelaena (Moure, 1943)

- Metade dorsal dos mesepisternos com pêlos pretos. Faixas dos tergos não estreitadas no meio. Esternos com pêlos e cerdas enegrecidos. Brasil: Rio de Janeiro, Minas Gerais .......................... grafi sp.n.

30. Cabeça com pêlos brancos ou levemente amarelados. Segundo ao quarto tergo com larga margem translúcida amarela. Tomento basal branco largo no segundo e terceiro tergos, reduzindo a faixa discal castanha do segundo e dividindo a do terceiro em duas faixas laterais. Argentina: Santa Fé; Brasil: Paraná, Santa Catarina, Rio Grande do Sul ........ inducens Brèthes, 1910

- Cabeça com pêlos enegrecidos pelo menos no vértice. Segundo ao quarto tergo com margem castanha. Tomento branco basal largo só no segundo tergo, o terceiro com tomento basal castanho ..................... 31 
31. Segundo ao quarto tergo com pilosidade branca apical porém deixando ver o tegumento. Paraguai, San Bernardino; Argentina: Salta, Chaco, Misiones; Brasil: Pará, Paraná, Santa Catarina . . . . . . . . . . fiebrigi Brèthes, 1909

- Tergos com faixas apicais amarelo-douradas densas e largas, ocultando o tegu-

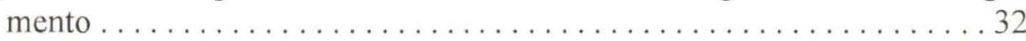

32. Metade distal do mesoscuto com os pontos muito esparsos, os intervalos grandes deixando áreas quase glabras. Terceiro e quarto esternos com franja branca encoberta pelas cerdas amarelo-fulvas, os pêlos da franja de tamanho irregular.Brasil: São Paulo, Paraná, Santa Catarina, Rio Grande do Sul .......

larocai sp.n.

- Metade distal do mesoscuto com os intervalos entre os pontos medindo 2 a 4 diâmetros de ponto. Terceiro e quarto esternos com franja branca, não encobertas pelas cerdas castanhas, os pêlos da franja de comprimento uniforme. Argentina: Tucumán, Catamarca, Córdoba, Santiago del Estero; Brasil: Espírito Santo, Paraná, Santa Catarina, Rio Grande do Sul . . bonaerensis Holmberg, 1903

33. Primeiro tergo com margem estreita desprovida de pontos grandes medindo aproximadamente um diâmetro de flagelo .............. mirnae sp.n.

- Primeiro tergo com larga margem desprovida de pontos grandes, mais larga que dois diâmetros de flagelo, ou estreita no meio e larga aos lados . . . . . . 34

34.Mesoscuto, escutelo e parte do metanoto com pêlos bicoloridos, castanhos na ponta e cremosos nos dois terços basais. Brasil: Ceará, Maranhão ........ . uncicornis (Ducke, 1910)

- Pêlos castanhos do mesoscuto e escutelo sem o aspecto descrito acima . . . . . 35

35. Paroculares superiores largamente foscas, com micro-reticulação densa. Basitarsos anteriores com pêlos amarelos. Tergos com larga margem translúcida ferrugíneo-avermelhada. Equador: Loja ............. ecuatoriana sp.n.

- Paroculares superiores variáveis, porém brilhantes quando com micro-reticulação. Basitarsos anteriores com pilosidade variável, enegrecida quando com os tergos ferrugíneo-avermelhados ...................... 36

36. Tergos com margem translúcida larga amarelo-esbranquiçada. Basitarsos anteriores com mescla de pêlos esbranquiçados e castanhos no lado externo. Argentina: Tucumán, Entre Rios . . . . . . . . . . . . . villosa sp.n.

- Tergos com larga margem ferrugíneo-avermelhada ou castanho-enegrecida. Basitarsos anteriores com pilosidade variável . . . . . . . . . . . . . 37

37. Margem translúcida dos tergos ferrugíneo-avermelhada. Base do propódeo com faixa grosso-pontuada larga. Basitarsos anteriores com pêlos castanho-enegrecidos. Brasil: Minas Gerais, Espírito Santo, Rio de Janeiro, São Paulo, Paraná ............................ cnecomala (Moure,1944)

- Margem dos tergos castanho-enegrecida. Base do propódeo e basitarsos variáveis 
38. Tíbias posteriores com cerdas castanhas na face externa, ao longo do comprimento ou ao menos junto à placa basitibial . . .................. 39

- Tíbias posteriores com cerdas amareladas ou esbranquiçadas . . . . . . . . 41

39. Cerdas castanhas das tíbias posteriores somente junto à placa basitibial . . . 40

- Cerdas castanhas no lado externo das tíbias posteriores, ao longo do comprimento das tíbias. Equador: Loja . . . . . . . . . . . . . . . . aurea sp.n.

40.Paroculares superiores brilhantes, sem micro-reticulação, com elevação do tegumento junto ao vértice, até meia distância entre os olhos e ocelos. Brasil: Bahia, Espírito Santo . . . . . . . . . . . . . . . . solangeae sp.n.

- Paroculares superiores micro-reticuladas, foscas e com pontos grandes até junto às órbitas, sem elevação do tegumento junto ao vértice. Argentina: Catamarca .................................... albinoi sp.n.

41.Base do propódeo com estreita faixa grosso-pontuada. Mesoscuto quase glabro na metade posterior do disco. Equador: Loja, Guayas . ............... .............................. pacifica (Cockerell, 1914)

- Base do propódeo com larga área grosso-pontuada. Mesoscuto com pontuação densa, os espaços entre os pontos igualando os mesmos ou menores, sem área glabra no disco. Argentina: Formosa, Córdoba, Santa Fé, Entre Rios . . desiderata (Holmberg, 1903)

\section{MACHOS}

1. Tíbias e basitarsos medianos largos e achatados. Esternos com pilosidade longa ereta e densa, sem franja apical. Face ventral dos basitarsos medianos com pêlos espatulado-curtos. Trocanteres posteriores carenados .......... 2

- Pernas normais. Segundo ao quinto esterno com pilosidade curta decumbente, com franja apical também decumbente. Face ventral dos basitarsos medianos com cerdas lisas . . . . . . . . . . . . . . . . . . . . . 5

2. Sexto esterno com quatro carenas, duas paralelas aos bordos laterais e duas medianas convergentes para a ponta. Flagelômero distal comprimido e mais largo que os adjacentes ................. tandilensis Holmberg, 1884

- Sexto esterno somente com duas carenas junto aos bordos laterais. Flagelômero distal com a mesma largura dos anteriores ou atenuado ............ 3

3.Tíbias medianas com micro-pilosidade esparsa na face ventral. Trocanteres posteriores com cerdas curtas ao longo da carena. Tergos com faixas apicais amarelas e pilosidade basal enegrecida. Tíbias posteriores com carena fina e longa no lado interno ..................... paranaensis $\mathbf{s p . n .}$

- Tíbias medianas com tufo basal esparso de pêlos longos, na face ventral. Trocanteres posteriores com cerdas grossas subapicais longas, junto à carena. Tergos com pilosidade amarela, sem faixas escuras. Tíbias posteriores com

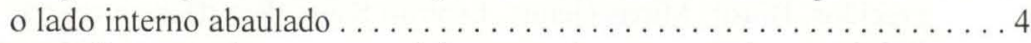

4. Tíbias medianas tão largas como dois terços do seu comprimento. Mesoscuto e escutelo com pilosidade enegrecida predominando ............... . paraguayensis (Brèthes, 1909) 
- Tíbias medianas tão largas como metade do seu comprimento. Mesoscuto e escutelo com pêlos cremosos, ou com área castanha reduzida no mesoscuto e só no disco do escutelo ................desiderata (Holmberg, 1903)

5. Clípeo preto sem áreas amarelas. Fêmures anteriores com pilosidade longa, quase duas vezes sua largura máxima, na face anterior. Tergos com faixas pilosas castanhas no disco e no ápice branco-amareladas .... inducens Brèthes, 1910

- Clípeo amarelo ou com grande área preta junto à sutura epistomal; quando preto, os tergos sem faixas pilosas apicais claras. Fêmures anteriores com pilosidade tão longa como sua largura na face anterior . . . . . . . . . . 6

6. Clípeo amarelo porém com área preta junto à sutura epistomal . . . . . . . . 7

- Clípeo amarelo, com duas pequenas nódoas pretas, unidas ou não às fóveas

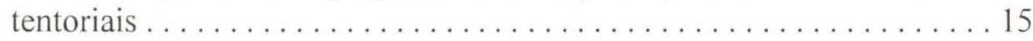

7. Área ventral dos mesepisternos com pêlos plumosos . . . . . . . . . . . . 8

- Área ventral dos mesepisternos com pêlos modificados . . . . . . . . . . . 9

8. Pilosidade branca. Base do propódeo com faixa grosso-pontuada muito larga, resultando uma área discal sem pontos pouco maior que o diâmetro do flagelo. Argentina: Tucumán, Catamarca . . . . . . . . . . renatoi sp.n.

- Pilosidade amarela nos tergos; amarelo-acastanhada no mesoscuto e castanha no escutelo. Base do propódeo com faixa grosso-pontuada estreita no meio e alargando aos lados ..................... ecuatoriana sp.n.

9. Área ventral dos mesepisternos com pêlos espatulado-longos. Fêmures posteriores com a face ventral quase reta, os contornos levemente carenados. Carenas laterais do sexto esterno afastadas do bordo, formando um arco recurvo longo a cada lado . . . . . . . . . . . . . . . . . . . . 10

- Área ventral dos mesepisternos com pêlos espatulado-curtos ou lanceolados. Fêmures posteriores com a face ventral abaulada ou levemente reta para o ápice. Carenas laterais do sexto esterno variáveis . .............. 11

10. Pilosidade do mesoscuto e escutelo preta. Terceiro ao quinto esterno com o bordo glabro no meio e franjas somente nos flancos. Tergos com faixas pilosas apicais brancas ................... aureocincta Urban, 1968

- Pilosidade do mesoscuto e escutelo amarelo-fulva. Terceiro ao quinto esterno com franjas nos flancos e pêlos esparsos entre as franjas. Tergos com faixas pilosas apicais amareladas ........ minarum (Bertoni \& Schrottky, 1910)

11. Tergos com pêlos pretos na base e faixas apicais brancas ou amareladas . . . 12

- Tergos com toda a pilosidade clara, sem faixas escuras . . . . . . . . . . 13

12. Segundo flagelômero mais longo que o dobro da sua largura $(0,54: 0,24)$. Área ventral dos mesepisternos com pêlos espatulado-curtos. Trocanteres medianos com pilosidade muito curta e esparsa na face ventral. Terceiro ao quinto tergo com faixa pilosa apical branca estreita. Brasil: Amazonas . 
- Segundo flagelômero mais curto que o dobro da sua largura $(0,36: 0,20)$. Área ventral dos mesepisternos com pêlos lanceolados. Trocanteres medianos com pilosidade curta, densa, decumbente e alongada para o bordo. Terceiro ao quinto tergo com faixa pilosa apical larga amarela. Brasil: Paraná ..... fulvonigra Urban, 1988

13. Área ventral dos mesepisternos com pêlos lanceolados. Segundo flagelômero quase igualando o dobro do primeiro. Fêmures posteriores quase glabros na face voltada para as tíbias. Brasil: Bahia ............ sertanicola sp.n.

- Área ventral dos mesepisternos com pêlos espatulado-curtos. Segundo flagelômero pouco maior ou igual ao primeiro. Fêmures posteriores com pilosidade fina e densa na face voltada para as tíbias . . . . . . . . . . . . . 14

14. Pilosidade do escutelo amarela. Flagelômeros distais inteiramente enegrecidos. Quinto esterno com área médio-apical desprovida de franja. Raramente com clípeo preto ................ richardiae Bertoni \& Schrottky, 1910

- Pilosidade do escutelo castanha. Flagelômeros amarelo-acastanhados no lado ventral, inclusive os distais. Quinto esterno com franja apical decumbente . . similis Urban, 1988

15. Disco do clípeo achatado. Pilosidade da área ocelo-ocular densa, encobrindo o tegumento .......................... dama (Vachal, 1904)

- Disco do clípeo levemente abaulado. Pilosidade da área ocelo-ocular normal, não encobrindo o tegumento ........................ 16

16. Tergos com pêlos pretos na base e claros na faixa apical, geralmente do terceiro

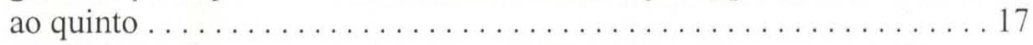

- Tergos com pilosidade de colorido uniforme .................... 27

17. Mesepisternos com pêlos plumosos ventralmente ............... 18

- Mesepisternos com pêlos modificados na face ventral . .............. 22

18. Trocanteres medianos com pêlos espatulado-curtos de tamanho uniforme até o bordo posterior, resultando um aspecto aveludado. Mesoscuto e escutelo branco-pilosos. Argentina: Salta, Tucumán, Córdoba, Catamarca; Brasil: Rio Grande do Sul ........................ sexcincta sp.n.

- Trocanteres medianos sem o aspecto descrito acima, com pêlos longos junto ao bordo posterior. Mesoscuto e escutelo com pêlos pretos, amarelo-acastanhados ou castanhos no disco . . . . . . . . . . . . . . . . . . . . . 19

19. Mesoscuto e escutelo com pêlos pretos ................ setigera sp.n.

- Mesoscuto e escutelo amarelo-acastanhados ou castanhos somente no disco. 20

20.Clípeo com as nódoas laterais pretas alargadas para as fóveas tentoriais e fundidas ao tegumento preto adjacente. Clípeo micro-reticulado, mais densamente nos lados. Mesepisternos densamente micro-reticulados entre os pontos. Equador: Azuay ................... montanicola sp.n.

- Nódoas pretas do clípeo próximas às fóveas tentoriais. Clípeo sem micro-reticulação entre os pontos. Mesepisternos com micro-reticulação fraca entre os

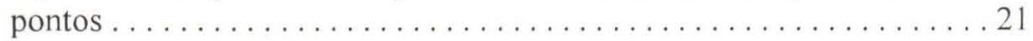


21. Tergos com faixas pilosas apicais castanho-bronzeadas ou amarelo-bronzeadas. Pernas com o tegumento enegrecido inclusive nos basitarsos medianos e posteriores. Mesoscuto e escutelo com pilosidade amarelo-acastanhada ... bahiana sp.n.

- Tergos com faixas pilosas apicais amarelo-palha. Pernas com o tegumento castanho-amarelado nos basitarsos e demais tarsômeros, também em parte das tíbias. Mesoscuto e escutelo com pilosidade castanha na área discal ... . . bonaerensis Holmberg, 1903

22. Mesoscuto com pilosidade preta. Mesepisternos com pêlos lanceolados na área ventral . . .

- Mesoscuto com pilosidade amarela ou fulva, ao menos em parte. Mesepisternos com pêlos modificados variáveis na área ventral . .............. 24

23. Pilosidade branca predominando na cabeça, enegrecida somente no vértice. Mesepisternos branco-pilosos .................. fiebrigi Brèthes, 1909

- Pilosidade da cabeça enegrecida na fronte, paroculares e vértice. Mesepisternos com pêlos enegrecidos, passando a esbranquiçados na área ventral ....... ........................................ grafi sp.n.

24. Face ventral dos mesepisternos com pêlos espatulado-longos . ........... minarum (Bertoni \& Schrottky, 1910)

- Face ventral dos mesepisternos com pêlos lanceolados .

25. Metade distal do mesoscuto e todo o escutelo com pêlos enegrecidos ........ ochromelaena (Moure, 1943)

- Mesoscuto e escutelo amarelo-fulvos .

26. Tergos com larga faixa apical de pilosidade esbranquiçada, mais larga que dois diâmetros de ocelo. Ápice do terceiro ao quinto esterno sem franja medianamente. Larga margem translúcida clara nos tergos ......... larocai sp.n.

- Tergos com faixa branco-pilosa apical estreita, igualando um diâmetro de ocelo. Ápice do terceiro ao quinto esterno com franja. Sem margem translúcida clara nos tergos . ..................... thoracica (Smith, 1854)

27. Flagelômero apical afilado, mais estreito que os anteriores. Face ventral dos trocanteres medianos com pilosidade esparsa e curta .............. uncicornis (Ducke, 1910)

- Flagelômero apical semelhante ao adjacente, não estreitado. Face ventral dos trocanteres medianos com pilosidade densa, com aparência aveludada ou não .28

28. Mesepisternos com pêlos modificados decumbentes formando uma área distinta na face ventral . . . . . . . . . . . . . . . . . . . . . . . 29

- Mesepisternos com pêlos plumosos na face ventral . . . . . . . . . . . . . 33

29. Face ventral dos mesepisternos com pêlos espatulados . . . . . . . . . . 30

- Face ventral dos mesepisternos com pêlos lanceolados .............. 31 
30. Mesepisternos com pêlos espatulado-longos na face ventral. Primeiro flagelômero pouco menor que o segundo. Segundo flagelômero pouco maior que duas vezes seu diâmetro. Trocanteres medianos com pilosidade curta até o bordo posterior. Brasil: Minas Gerais . ............. mielkei sp.n.

- Mesepisternos com pêlos espatulado-curtos na face ventral. Primeiro flagelômero igualando a metade do segundo. Segundo flagelômero tão longo como três vezes seu diâmetro. Trocanteres medianos com a pilosidade alongando em direção ao bordo posterior .......... vulpecula Bertoni \& Schrottky, 1910

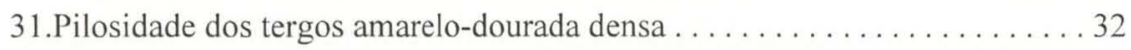

- Pilosidade do terceiro ao quinto tergo preta, esparsa no disco ............. thoracica (Smith, 1854)

32. Sexto esterno com carenas laterais curtas, afastadas dos bordos, formando um semi-círculo a cada lado. Pêlos castanhos na metade distal do disco do mesoscuto e no do escutelo. Face ventral dos fêmures medianos com pilosidade decumbente curtíssima somente na base ........ carinata sp.n.

- Sexto esterno com as carenas laterais afastadas dos bordos formando um arco recurvo longo a cada lado. Mesoscuto e escutelo sem pêlos escuros. Face ventral dos fêmures medianos com pilosidade curtíssima decumbente ocupando a metade basal ..................... claudii Urban, 1988

33. Fêmures medianos com pêlos espatulado-curtos, na metade basal da face ventral. Trocanteres medianos com pêlos espatulado- curtos, densos e com aspecto aveludado. Brasil: Mato Grosso .................... cacerensis sp.n.

- Fêmures medianos com pêlos ramificados. Trocanteres medianos e posteriores

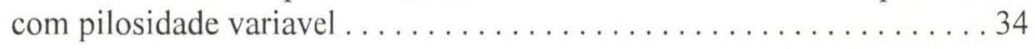

34. Trocanteres medianos com pilosidade densa, curta, aveludada e distinta do restante na face ventral. Trocanteres posteriores com pilosidade curta e uniforme, sem aspecto aveludado . ............... villosa sp.n.

- Trocanteres medianos com pilosidade curta e densa, decumbente, porém alongada para o bordo posterior. Trocanteres posteriores não como acima, com pilosidade alongada uniforme ou alongada somente na base ........... 35

35. Clípeo com micro-reticulação tanto nos pontos como nos intervalos. Pilosidade do mesoscuto e escutelo amarela a amarelo-fulva, sem pêlos castanhos no

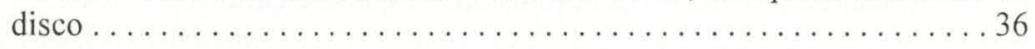

- Clípeo brilhante ou com fraca micro-reticulação em pequenas áreas entre os pontos. Pilosidade do mesoscuto e do escutelo variável ........... 37

36. Clípeo com pontuação densa irregular, os intervalos menores que um diâmetro de ponto, com carena mediana na área basal. Primeiro flagelômero maior que a metade do segundo. Fêmur mediano com pilosidade longa na face posterior, tão longa como a largura do fêmur ............ albinoi sp.n.

- Clípeo com pontuação rasa, intervalos entre os pontos medindo um a dois diâmetros de ponto, sem carena mediana. Segundo flagelômero medindo aproximadamente três vezes o comprimento do primeiro. Fêmur mediano 
com pilosidade curta na face posterior, medindo aproximadamente um terço da largura do fêmur. Brasil: Bahia . . . . . . . . . . . . clypeata sp.n.

37. Clípeo amarelo com duas nódoas arredondadas pretas orladas por tegumento

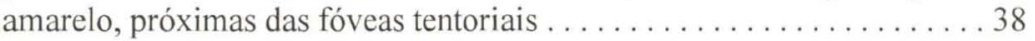

- Clípeo amarelo com duas nódoas pretas laterais unidas ao tegumento preto

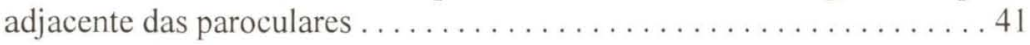

38. Pilosidade castanho-enegrecida em quase todo o dorso do mesosoma, inclusive no metanoto, com pêlos claros somente na base do mesoscuto. Pêlos castanho-enegrecidos no vértice, atrás dos ocelos . . . . . . . . . buzzii sp.n.

- Pilosidade do dorso do mesosoma amarela ou em parte castanha, no metanoto branco-amarelada. Pêlos esbranquiçados ou com mescla de castanho no vértice, atrás do ocelo mediano . . . . . . . . . . . . . . . . . . 39

39. Mesoscuto e escutelo com pilosidade amarela . . . . . . . . . . . . . 40

- Mesoscuto com pilosidade castanha ao menos no disco, e castanha no escutelo . marinonii sp.n.

40. Tergo basal com margem lisa desprovida de pontos muito estreita e pouco distinta. Tíbias e basitarsos posteriores com revestimento cerdoso denso, quase ocultando o tegumento . . . . . . . . . . . . . chilena sp.n.

- Tergo basal com margem lisa desprovida de pontos mais larga que um diâmetro de ocelo. Tíbias e basitarsos posteriores com revestimento cerdoso normal, as cerdas deixando ver claramente o tegumento . cnecomala (Moure, 1944)

41. Segundo flagelômero pouco maior que o primeiro, alcançando até pouco mais de duas vezes o primeiro. Esternos com franja apical cremosa a acastanhada. Placa medianas do sétimo esterno curtas e pouco conspícuas . . . . . . . . 42

- Segundo flagelômero aproximadamente três vezes o comprimento do primeiro.

Esternos com franja apical branca. Placas medianas do sétimo esterno longas, igualando o comprimento do esterno na linha média. Argentina: Catamarca . . . . . . . . . . . . . . . catamarcensis sp.n.

42. Base do propódeo com faixa grosso-pontuada larga . . . . . . . . . . . 43

- Base do propódeo com faixa grosso-pontuada estreita . pacifica (Cockerell, 1914) 43. Segundo flagelômero aproximadamente igual ao dobro do primeiro . . . . . 44 - Segundo flagelômero curto, pouco mais longo que o primeiro . . moureana sp.n. 44. Mesoscuto e escutelo com pilosidade enegrecida no disco. Ápice do tergo basal com área lisa estreita, desprovida de pontos grandes . . . . . . . aurea sp.n.

- Mesoscuto e escutelo com pilosidade cremosa. Tergo basal com área lisa desprovida de pontos grandes medindo aproximadamente o dobro do diâmetro dos ocelos ......................... pubescens (Smith, 1879) 


\section{REFERÊNCIAS BIBLIOGRÁFICAS}

BRÈTHES. 1910. Himenópteros Argentinos. An. Mus. Nac., Buenos Aires, 20 (13): 205-316.

HolmberG, E.L. 1884. Viajes á las Sierras del Tandil y de la Tinta. Insectos. I. Himenópteros - Hymenoptera. Actas de la Academia Nacional de Ciencias en Córdoba 5: 117-136.

MiCHENER, C.D. \& J.S. Moure. 1956. The Generic positions of certain south american Eucerine Bees (Hymenoptera, Apoidea). Dusenia 7 (5): 277-290.

MoURE, J.S. 1943. Notas sôbre abelhas da coleção Zikán. Rev. Ent., Rio de Janeiro, 14 (3): 447-484.

Moure, J.S. \& C.D. Michener. 1955. A Contribution Toward the Classification of Neotropical Eucerini (Hymenoptera, Apoidea). Dusenia 6 (6): 239-326.

UrBAN, D. 1968. As espécies do gênero Melissoptila Holmberg, 1884 (Hymenoptera, Apoidea) Revta bras. Ent. 13: 1-94.

Recebido em 24.X.1996; aceito em 03.XI.1997. 